\title{
Jihad na África Ocidental durante a "Era das Revoluçóes": em direção a um diálogo com Eric Hobsbawm e Eugene Genovese
}

\author{
Paul E. Lovejoy*
}

\section{RESUMO}

Este artigo trata das relações entre movimentos sociais e políticos ocorridos na África Ocidental em fins do século XVIII e início do século XIX, em especial o jihad sudanês, e os processos de transformação global do Ocidente nesse mesmo período. Abre-se um diálogo com os trabalhos de Erick Hobsbawm e Eugene Genovese, analisando criticamente suas abordagens sobre a influência das sociedades do oeste africano nos eventos que têm lugar no mundo atlântico durante a chamada "era das revoluçóes". O artigo discute, ainda, a perspectiva a partir da qual vêm sendo estudadas as rebeliōes escravas nas Américas, que pouco considera o contexto africano e ressalta apenas as influências das mudanças revolucionárias na Europa Ocidental. Nesse sentido, também questiona a historiografia que analisa o surgimento do "Atlântico Negro", a qual não atribui a devida importância aos determinantes originados no interior da África, fundamentais nesse processo.

Palavras-chave: jihad; escravidão; resistência; África Ocidental; era das revoluções.

\section{ABSTRACT}

This paper investigates the relationship between West Africa social and political movements in late eighteenth- and early nineteenth centuries, especially the Sudanese jihad, and the processes of Western global transformation during the same period. It opens a dialogue with the work of Eric Hobsbawn and Eugene Genovese, critically analyzing their approach of the influence of Western Africa's societies on the events taking place in the Atlantic world through the so-called "age of revolutions." The article also questions the perspective adopted in studies of slave rebellions in the Americas, which barely consider the African context, and highlight only the influence of Western Europe's revolutionary changes. In that sense, the paper also questions the historiography of the "Black Atlantic" emergence, which does not

Artigo recebido em 20 de julho de 2013 e aceito em 30 de novembro de 2013.

DOI - http://dx.doi.org/10.1590/2237-101X015028002

* Doutor em história pela University of Wisconsin, EUA, Distinguished Research Professor e Canada Research Chair em African History na York University, Canadá. Toronto, Canadá. E-mail: plovejoy@yorku.ca. 
JiHAd Na ÁFrica Ocidental durante a "Era das Revoluçốes":

em direçấo A UM Dí́logo com ERIC HobsbaWm e Eugene GENovese

Paul E. Lovejoy

attribute due importance to determining factors originating within Africa, crucial in that process.

Keywords: jihad; slavery; resistance; Western Africa; age of revolutions.

A questão da resistência está no cerne da história social e cultural da escravidão. ${ }^{1}$ Os historiadores, em particular, têm se preocupado em comparar as resistências escravas em diferentes colônias europeias nas Américas, com particular atenção em como a revolução em São Domingos e o estabelecimento do Estado independente do Haiti influenciaram outros eventos subsequentes. Este artigo dialoga com dois estudiosos cujos trabalhos influenciaram a historiografia. Em primeiro lugar, Eric Hobsbawm e a sua caracterização do período de 1789 à 1848 como a "era das revoluçôes", que resultou na "transformação do mundo (...) devido ao que é aqui chamado de 'revoluçóes duplas' — a Revolução Francesa de 1789 e a contemporânea Revolução Industrial (inglesa)". ${ }^{2}$ Em segundo, com Eugene Genovese, que propôs 1793 como um ano divisor de águas nas formas de resistência à escravidão. Os acontecimentos revolucionários em São Domingos e a independência do Haiti teriam sido marcos fundadores de novas formas de resistência. ${ }^{3}$ Embora os estudos de Hobsbawm se limitem

\footnotetext{
${ }^{1}$ Uma versão preliminar deste texto foi apresentada na conferência "Les résistances à l'esclavage dans le monde atlantique français à l'ère des Révolutions (1750-1850)", na McGill University, em Montreal, de 3 a 4 de maio de 2013. Agradeço a Rina Cáceres Gomez pelas discussóes que auxiliaram na conceitualização deste artigo. Myriam Cottias, Nielson Bezerra, Carlos da Silva Jr., Elaine Moreira, Mariana Cândido, Feisal Farah, Henry B. Lovejoy, Jennifer Lofkrantz, Suzanne Schwarz, Vanessa Oliveira, Katrina Keefer e Mônica Lima e Souza fizeram comentários e ofereceram assistência de diversas formas, desde a pesquisa à tradução. Também agradeço ao Conselho de Pesquisa de Ciências Sociais e Humanidades do Canadá e à Cátedra de Pesquisa em História da Diáspora Africana do Canadá, cujo apoio à minha pesquisa tem sido indispensável e é extremamente apreciado. O argumento aqui exposto não é novo; ele foi apresentado por mim na primeira edição do Transformations in slavery, em 1983 e, de fato, anteriormente em uma conferência organizada por Michael Craton em 1979. Ver: LOVEJOY, Paul E. Indigenous African slavery. In: CRATON, Michael (Ed.). Roots and branches: current directions in slave studies. Toronto: Pergamon Press, 1979, originalmente publicado em Historical Reflections/Reflexions Historiques, v. 6, n. 1, p. 19-61, 1979, com comentários de Igor Kopytoff e Frederick Cooper, p. 62-83.

${ }^{2}$ HOBSBAWM, Eric. The age of revolution, 1789-1848 [1962]. Nova York: Vintage Books, 1996. p. ix.

${ }^{3}$ GENOVESE, Eugene. From rebellion to revolution: Afro-American slave revolts in the making of the Modern World. Baton Rouge, LA: Louisiana State University Press, 1979. Claro, James chamou atenção para a origem europeia da revolução haitiana e consequentemente influenciou ambos, Hobsbawm e Genovese. James, C. L. R. The black jacobins: Toussaint l'Ouverture and the San Domingo Revolution. 2. ed. Nova York: Random House, 1963. Do mesmo modo, Herbert Aptheker (American Negro Slave Resistance. Nova York, 1944) documentou as dinâmicas da resistência escrava nos Estados Unidos e seu trabalho pioneiro, geralmente ignorado pela literatura, ajudou a chamar a atenção do conhecimento acadêmico para o assunto. Ver: OKIHIRO, Gary; APTHEKER, Herbert (Ed.). Resistance not acquiesence: studies in African, Afro-American and Caribbean history. Amherst, MA: University of Massachusetts Press, 1986.
} 
às transformaçóes no noroeste da Europa e, por extensão, aos impérios britânico e francês, assim como à América Latina independente, ele estava ciente que reflexos foram sentidos na África e em outros lugares. No entanto, Hobsbawm associa, em seus estudos, revoluçóes e transformaçôes a espaços restritos à Europa ocidental, negligenciando a possibilidade de eventos como os movimentos do jihad na África Ocidental terem tido algum impacto na formação do mundo moderno ou ainda que esses eventos africanos fossem contemporâneos à era das revoluçóes ocidentais. Ao mesmo tempo, a análise de Genovese sobre a natureza da resistência escrava também não considera as intersecçôes das diferentes "eras de revolução" na África e no mundo atlântico. Este artigo procura demonstrar as formas pelas quais a África Ocidental participou ou não desses eventos globais propostos por Hobsbawm e Genovese.

Apesar da importância da Revolução Industrial na Grã-Bretanha e da Revolução Francesa, Hobsbawm estava equivocado ao defender que "os estados islâmicos estavam tão agitados com crises; [que] a África estava exposta à conquista direta” durante o período 1789-1848. ${ }^{4}$ Hobsbawm podia estar correto com relação ao Estado otomano durante a era napoleônica e as reformas no Egito, assim como sobre a conquista britânica em partes islamizadas da Índia, porém suas observações não se estendem à África Ocidental. Ao contrário, a África não estava aberta à "conquista direta”, pelo menos não antes da conquista francesa da Argélia otomana em 1830-1847 e a contínua ocupação francesa de St. Louis e Goré. Vale lembrar que a exploração europeia do vale do rio Senegal só ocorreu após 1854. O bloqueio britânico da costa ocidental africana após 1808 pode ter abalado os estados localizados no litoral da África, porém o impacto no interior foi praticamente nulo. O bloqueio na verdade reforçou os objetivos do movimento do jihad islâmico, ou seja, isolar o interior da África do mundo atlântico, sem contudo afetar a continuidade da instituição da escravidão na África Ocidental. Na África Austral, a Grande Jornada dos Boers pós-1834 foi uma resposta às políticas abolicionistas britânicas e aos esforços imperiais para controlar uma população que não estava disposta a se tornar súdita do império britânico. Em outras palavras, não foi exatamente uma conquista colonial. Apesar de Genovese ter reconhecido a importância da resistência muçulmana à escravidão e da revolta dos malês na Bahia, ele foi incapaz de identificar revoltas semelhantes na colônia britânica de Serra Leoa, que ocorreram praticamente ao mesmo tempo, ou ainda as conexões entre a resistência iorubá em Cuba com os jihad na África Ocidental.

Este artigo busca um diálogo com os estudos de Hobsbawm e Genovese. Os dois autores negligenciaram a importância dos movimentos do jihad do final do século XVIII e início do século XIX e as enormes contribuiçóes de tais eventos para a compreensão da era das revoluções. E, visto que a produção intelectual desses dois autores tornou-se leitura obrigatória para historiadores, a negligência acabou por ofuscar uma rica produção intelectual realizada no continente africano sobre os eventos daquela época. Aspecto central para este artigo e

\footnotetext{
${ }^{4}$ HOBSBAWM, Eric. The age of revolution, op. cit. p. 3.
} 
JiHAd Na ÁFrica Ocidental durante a "Era das Revoluçốes":

meu diálogo com Hobsbawm e Genovese é o reconhecimento da necessidade de ampliarmos nossa compreensáo sobre a "era das revoluçóes", o que exige a utilizaçáo de uma metodologia histórica que identifique fontes e interpretaçóes abertas a novas hipóteses e conceitos. ${ }^{5}$ O principal problema reside em que tanto Hobsbawm como Genovese criaram um modelo para o mundo moderno que oferece uma visão eurocêntrica sobre a história do mundo ocidental. A questão a ser abordada diz respeito à possibilidade ou não de negligenciar a África - neste caso, a África Ocidental -, na reconstruçáo da história do mundo atlântico durante o período da "era das revoluçôes".

\section{Perspectivas sobre a história}

Esse artigo resgata o lugar da África Ocidental islâmica no mundo atlântico durante a "era das revoluções". Na África Ocidental, o Islă, e não a identificação como hausa, iorubá, manden, diula etc., prevalecia. A etnicidade era uma extensão da identidade política que, transferida à Bahia no contexto do movimento do jihad na África Ocidental, sofreu transformaçóes. Ou seja, se o levante dos malês deve ser considerado dentro de uma perspectiva atlântica durante a "era das revoluçôes", então ele também deve ser interpretado no contexto dos acontecimentos da África Ocidental. A ênfase na dimensão transatlântica acabou por diminuir a importância do Sudão Central. Meu diálogo com a produção acadêmica de Hobsbawm e Genovese inclui, inevitavelmente, um desafio para outros estudiosos. O papel dos muçulmanos na insurreição de 1835, na Bahia, é bem documentado. Do mesmo modo, a presença de muçulmanos escravizados nas Américas é reconhecida e está bem estabelecida na historiografia. Apesar disso, a possibilidade de conexáo com os jihad parece ainda não ter sido reconhecida como importante no contexto da "era das revoluçôes" e das grandes transformaçôes associadas à resistência escrava nas Américas.

A historiografia prioriza as influências africanas na formação das sociedades escravistas nas Américas, embora esta não tenha sido necessariamente uma preocupação de Hobsbawm. A sua "era das revoluçóes" enfatizava as mudanças sociais e econômicas na Europa e nas Américas, dando pouca atenção para as influências originárias da África. Embora a

\footnotetext{
${ }^{5}$ Enquanto Genovese (From rebellion to revolution, op. cit. p. 28-32) discute a influência muçulmana na insurreição na Bahia, ele parece desconhecer a produção acadêmica acerca do jihad na África Ocidental. Clyde Ahmed Winters tenta entender essa influência, assim como Pierre Verger e Roger Bastide, mas novamente sem uma apreciação completa do que foi produzido na África Ocidental. WINTERS, Clyde Ahmed. The Afro-Brazilian concept of jihad and the 1835 Slave Revolt. Afrodiaspora: Journal of the African World, v. 2, p. 87-91, 1984. Para uma interpretação melhor e mais recente, ver GOMEZ, Michael. Black crescent: the experience and legacy of African Muslims in the Americas. Cambridge: Cambridge University Press, 2005. p. 91-127. Também ver AUSTIN, Allan D. African Muslims in antebellum America: transatlantic struggles and spiritual struggles. Nova York: Routledge, 1997; AUSTIN, Allan D. African Muslims in antebellum America: a sourcebook. Nova York: Garland, 1984.
} 
JiHAd Na ÁFrica Ocidental durante a "Era das Revoluçốes":

em direçấo A UM Dí́logo com ERIC HobsbaWm e Eugene GENovese

Paul E. Lovejoy

interpretação de Genovese enfatize a importância de São Domingos como forma de resistência escrava e como esse evento se encaixava perfeitamente no paradigma de Hobsbawm, o conhecimento dele sobre as influências africanas era limitado. Embora esses dois estudiosos sejam importantes em qualquer discussão sobre revoluçóes ou resistência escrava, a contribuição de ambos ignorou o papel da África no mundo atlântico. ${ }^{6}$ Apesar dessas limitações, tanto Hobsbawm quanto Genovese tiveram papel fundamental na inclusão das revoltas escravas como parte da "era das revoluçôes". Contudo, minha intenção é enfatizar o papel do jihad na África Ocidental nesse contexto.

Para isso, eu proponho uma nova abordagem. Estudos sobre resistência escrava e revoluções no mundo atlântico tendem a concentrar-se nas Américas e na Europa, sem buscar entender o que acontecia na África. Hobsbawm é o criador da "era das revoluções", tanto como conceito como período cronológico. Os estudos sobre as mudanças históricas das últimas décadas do século XVIII até meados do século XIX tendem a vê-las como isoladas, como apenas uma fase na história da escravidão, e em particular o fim da escravidão é frequentemente associado às narrativas de mudanças revolucionárias na Europa Ocidental. $\mathrm{O}$ movimento abolicionista na Grã-Bretanha, a Revolução Francesa, a revolta em São Domingos, a independência do Haiti e a resistência dos escravos dos Estados Unidos ao Brasil figuram com destaque em nossa compreensão desse período da história e sua relação com a Revolução Industrial e as restrições constitucionais ou a eliminação pura e simples de regra monárquica na Europa Ocidental. Essa perspectiva sobre as revoluçóes do final do século XVIII e início do XIX, no entanto, tem seriamente subestimado e até mesmo ignorado o papel do jihad na África Ocidental. Por isso, o subtítulo deste trabalho é um "diálogo com Hobsbawm e Genovese”, e, por extensão, com a historiografia sobre a escravidão e a resistência escrava nas Américas assim como a produção acadêmica sobre o mundo atlântico e a história comparada.

\footnotetext{
${ }^{6}$ Entre as muitas contribuiçôes para o estudo da resistência e revolução escravas nas Américas, o caso de São Domingos se destaca, náo somente com James, Black Jacobins, mas também com trabalhos posteriores, como: FICK, Carolyn. The making of Haiti: the Saint Domingue Revolution from below. Knoxville: University of Tennessee Press, 1990; DUBOIS, Laurent; GARRIGUS, John D. Slave Revolution in the Caribbean, 17891804: a brief history with documents. Boston: Bedford; St Martin's, 2006; GEGGUS, David Patrick. Haitian revolutionary studies. Bloomington, IN: Indiana University Press, 2002; GEGGUS, David Patrick. (Ed.). The impact of the Haitian Revolution in the Atlantic World. Columbia, SC: University of South Carolina Press, 2001; DUBOIS, Laurent. Avengers of the New World: the story of the Haitian Revolution. Cambridge: Cambridge University Press, 2004; HURBON, Laënnec (Ed.). L'insurection des esclaves de Saint-Domingue (2223 août 1791). Paris: Karthala, 2000; BARTHÉLÉMY, Gérard. Dans la splendeur d’un après-midi d'histoire. Port-au-Prince: Henri Deschamps, 1996, reeditado como Créoles - bossales: conflit en Haïti. Petit-Bourg, Guadeloupe: Ibis Rouge, 2000; BARTHÉLÉMY, Gérard. Le rôle des bossales dans l'émergence d'une culture du marronage en Haïti. Cahiers d'études africaines, v. 148, 1997; CAUNA, Jacques de. Haïti, l'éternelle révolution: histoire de sa décolonization (1789-1804). Port-au-Prince: Deschamps, 2009; CÉSAIRE, Aimé. Toussaint-Louverture. La Révolution Française et le problème colonial. Présence africaine, 1960; DORIGNY, Marcel Haiti, première république noire. Paris, 2003; e SCHMIDT, Nelly. L'engrenage de la liberté. Caraïbes-XIX ${ }^{e}$ siècle. Aix-en-Provence: Université de Provence, 1995. Também ver CRATON, Michael. Testing the chains: resistance to slavery in the British West Indies. Ithaca: Cornell University Press, 1982.
} 
JiHAd Na ÁFrica Ocidental durante a "Era das Revoluçốes":

em direção a um diálogo com ERIC HobsbaWm e Eugene Genovese

Paul E. Lovejoy

Minha intervenção procura enfatizar os acontecimentos na África durante o período da "era das revoluçôes" e analisar como esses eventos influenciaram ou não os padrốes de transformaçôes nas Américas que, eventualmente, favoreceram a destruição da escravidão como instituição dominante. Como incorporar a história africana e os africanos nos eventos revolucionários das Américas? $\mathrm{Na}$ minha opinião, as influências africanas e, em particular, do movimento do jihad na África Ocidental tiveram um impacto profundo na formação de revoltas e diferentes manifestaçóes de resistência escrava nas Américas. Os jihad influenciaram os eventos na Bahia e, especificamente, a revolta malê de 1835, assim como a consolidaçáo da influência iorubá em Cuba. No âmbito da "era das revoluçóes" e da resistência das populaçôes escravizadas nas Américas, estou desafiando os especialistas no mundo atlântico a ampliarem seus horizontes e incluirem eventos históricos que tiveram lugar na África Atlântica e em seu interior. O interesse de Hobsbawm na transformação da natureza da forma de governar na era das revoluçóes, com o questionamento da validade das monarquias despóticas e o surgimento de regimes mais democráticos, poderia ser comparado às transformaçôes na África Ocidental nesse mesmo período - afinal, os jihad também transformaram as formas de governar na África Ocidental. Paralelo às várias formas de resistência escrava nas Américas e ao surgimento de uma "segunda escravidão" nas Américas no século XIX, uma série de jihad na África Ocidental resultou no aumento do número de escravos disponíveis concomitantemente ao fortalecimento da escravidão no Brasil, Cuba e Estados Unidos.

O historiador João José Reis demonstrou a natureza complexa do levante malê, no que diz respeito à identificação dos participantes quanto ao status legal (escravos/livres), base étnica (iorubá, ou seja, nagô, hausa etc.), e de acordo com as divisóes religiosas (islã, culto dos orixás etc.). Stuart Schwartz anteriormente havia chamado a atenção para as várias revoltas e conspiraçóes hausas que tiveram lugar na Bahia a partir de 1807.7 Além desses estudiosos, o historiador Michael Gomez reconheceu a importância da influência islâmica nas Américas. Porém essas contribuições não inserem os eventos nas Américas no contexto dos jihad e, particularmente, nas transformaçôes no Sudão Central. Sylviane Diouf examinou a resistência e revoluçấo no contexto das influências africanas e, no entanto, nem Gomez nem Diouf deram atenção ao Califado de Sokoto e seu papel na África Ocidental, que é precisamente o foco de minha análise. ${ }^{8}$ Diouf chegou a afirmar que as condiçóes para o jihad não estavam

\footnotetext{
${ }^{7}$ Na década de 1820, ocorreram dez insurreiçóes na Bahia e cinco na vizinha Sergipe de El-Rey nas quais escravos iorubás e ex-escravos estavam envolvidos. Ver: SCHWARTZ, Stuart. Sugar plantations in the formation of Brazilian society: Bahia, 1550-1835. Cambridge: Cambridge University Press, 1985. p. 486-487. Ver também SCHWARTZ, Stuart. Roceiros e rebeldes. Bauru: Edusc, 2001; SCHWARTZ, Stuart. Cantos e quilombos numa conspiração de escravos hausas. In: REIS, João José; GOMES, Flávio dos Santos (Ed.). Liberdade por um fio: história dos quilombos no Brasil. São Paulo: Companhia das Letras, 1997. p. 373-406. ${ }^{8}$ REIS, João José. Slave rebellion in Brazil: the Muslim uprising of 1835 in Bahia. Baltimore: Johns Hopkins University Press, 1993; DIOUF, Sylviane. Servants of Allah: African Muslims enslaved in the Americas. Nova York: New York University Press, 1998; GOMEZ, Michael. Muslims in early America. The Journal of Southern History, v. 60, n. 4, p. 671-710, 1994; GOMEZ, Michael. Black crescent, op. cit. p. 91-127. Ambos,
} 
JiHAd Na ÁFrica Ocidental durante a "Era das Revoluçốes":

em direçấo A UM Dí́logo com ERIC HobsbaWm e Eugene GENovese

Paul E. Lovejoy

presentes na Bahia na década de 1830, interpretação compartilhada por Reis. ${ }^{9}$ Da mesma forma, estudando Cuba, Manuel Barcia chamou a atenção para a presença de muçulmanos e destacou o papel dos jihad nos processos de captura e escravização. ${ }^{10}$ Henry B. Lovejoy demonstrou que os chamados "lucumis", muitas vezes sinônimo de iorubá em Cuba da mesma forma como o termo "nagô" era empregado no Brasil, estavam intimamente associados com o movimento do jihad. ${ }^{11} \mathrm{H}$. B. Lovejoy indica que o número de muçulmanos em Cuba foi realmente muito pequeno em comparação com as pessoas que vieram de Oyó e suas dependências, indivíduos esses que não eram muçulmanos. O perfil em Cuba parece ser contrário à demografia da Bahia, onde os muçulmanos estavam concentrados em maior número. ${ }^{12}$ Enquanto Barcia destacou a presença de muçulmanos em Cuba, ele não reconheceu que o seu número era realmente muito pequeno. ${ }^{13} \mathrm{~A}$ implicação, explorada por $\mathrm{H}$. B. Lovejoy, parece indicar decisóes conscientes de comerciantes na África com o objetivo de dividir os muçulmanos escravizados e os não muçulmanos em direção a diferentes destinos nas Américas. Ao que parece, os muçulmanos foram enviados esmagadoramente para a Bahia, enquanto

Roger Bastide (As religiôes africanas no Brasil. Contribuição a uma sociologia das interpretaçóes de civilizaçōes. São Paulo: Livraria Pioneira, 1989. p. 106) e Pierre Verger sugerem que os eventos na Bahia foram uma extensão do jihad. Ver: VERGER, Pierre. Flux et reflux de la traite des nègres entre le Golfe de Bénin et Babia de Todos os Santos du dix-septième au dix-neuvième siècle. Paris: Mouton, 1968; VERGER, Pierre. Trade relations between the Bight of Benin and Bahia, 17th-19th century. Ibadan: University of Ibadan Press, 1976; VERGER, Pierre. Fluxo e refluxo do tráfico de escravos entre o Golfo do Benin e a Babia de Todos os Santos, dos séculos XVII a XIX. São Paulo: Corrupio, 1987. Ver também BRAZIL, Etienne Ignace. Os malês. Revista do Instituto Histórico e Geográfico Brasileiro, v. 72, p. 69-126, 1909.

${ }^{9}$ DIOUF, Sylviane. Servants of Allah, op. cit. p. 158-159.

${ }^{10}$ BARCIA, Manuel. West African Islam in colonial Cuba. Slavery and Abolition, v. 35, n. 1, p. 1-14, 2014; e BARCIA, Manuel. An Islamic Atlantic revolution: Dan Fodio's Jihad and slave rebellion in Bahia and Cuba, 1804-1844. Journal of African Diaspora, Archaeology, and Heritage, v. 2, n. 1, p. 6-18, 2013.

${ }^{11}$ Para uma discussão acerca da terminologia, ver: LAW, Robin. Ethnicity and the slave trade: "Lucumi" and "Nago" as ethnonyms in West Africa. History in Africa, v. 24, p. 205-219, 1997; e LOVEJOY, Paul E. The Yoruba factor in the trans-Atlantic slave trade. In: FALOLA, Toyin; CHILDS, Matt D. (Ed.). The Yoruba diaspora in the Atlantic World. Bloomington: Indiana University Press, 2004. p. 40-55.

${ }^{12}$ LOVEJOY, Henry B. Old Oyo influences on the transformation of Lucumi identity in colonial Cuba. Tese (Ph.D.) — Univerisdade da Califórnia em Los Angeles, Los Angeles, 2012. Ver também: LOVEJOY, Henry B. Drums of Șàngó: Bàtá drums and the symbolic reestablishment of Oyọ in colonial Cuba, c. 1817-1867. In: TISHKEN, Joel; FALOLA, Toyin; AKINYEMI, Akintunde (Ed.). Sàngó in Africa and the African diaspora. Bloomington: Indiana University Press, 2009. p. 284-308; LOVEJOY, Henry B. The transculturation of Yoruba annual festivals: the Dia de Reyes in Colonial Cuba in the nineteenth century. In: INNES, Christopher; RUTHERFORD, Annabel; BOGAR, Brigitte (Ed.). Carnival - theory and practice. Trenton, NJ: Africa World Press, 2013. p. 33-50. Ver ainda LOVEJOY, Henry B. Re-drawing historical maps of the Bight of Benin hinterland, c. 1780. Canadian Journal of African Historical Studies, v. 47, n. 3, 2013; e "Historical maps" no website Desk of H. B. Lovejoy: <http://hlovejoy.wordpress.com/>.

${ }^{13}$ R. R. Madden, que esteve em Cuba entre 1834 e 1839, não faz referência a muçulmanos. Madden era um observador cuidadoso e experiente e claramente não encontrou nenhum muçulmano em Cuba. Madden falava árabe, viajou pelo Egito e pela África Ocidental e tinha amigos muçulmanos na Jamaica quando ele lá esteve em 1833-1834, antes de sua designaçáo para Cuba. Ver MADDEN, R. R. The island of Cuba: its resources, progress, and prospects, considered in relation especially to the influence of its prosperity on the interests of the British West India colonies. Londres: C. Gilpin, 1849. 
os iorubás de Oyó, não islamizados, eram enviados a Cuba. H. B. Lovejoy afirma que houve uma tentativa consciente de reconstituir os elementos do Estado de Oyó, incluindo a promoção de Xangô e a identificação deste com Santa Bárbara, dentro de grandes comunidades rurais e urbanas em Cuba dominadas pelos iorubás de Oyó. A comparação de H. B. Lovejoy entre Cuba e Bahia no âmbito da história do Atlântico Negro mostra diferentes formas de mobilização política e religiosa na resistência escrava.

Meu objetivo, portanto, é ampliar a discussão sobre a "era das revoluçôes" para além da identificação de Hobsbawm de uma dupla transformação industrial e política e do reconhecimento de Genovese do levante de São Domingos como ponto de virada da rebelião à revolução, para indagar como a África se ajusta a esses paradigmas. A consolidação de um campo de investigação que incide sobre o Atlântico negligenciou questóes de como as regióes da África contribuíram para a formação e o desenvolvimento do Atlântico Negro. Embora reconheçamos o desenvolvimento das "nações" de base étnica nas Américas e façamos a distinção entre as populaçóes nascidas na África e sociedades de crioulos/mulatos/mestiços que surgiram no Brasil, Caribe, América hispânica continental e América do Norte, há ainda uma negligência acerca de como os processos de mudança desencadeados pela expansão da escravidão nas Américas alteraram ou influenciaram o curso da história da África. Meu diálogo vai além de Hobsbawm e Genovese para incluir estudiosos do mundo atlântico. Minha intenção é discutir as contribuições de Paul Gilroy, Ira Berlin, Gwendolyn Midlo Hall, Jane Landers e outros para compreender como o surgimento de um "Atlântico Negro" foi moldado por influências do interior africano. ${ }^{14}$ Da mesma forma, uma perspectiva transnacional e global sugere modificaçóes das abordagens de Bernard Bailyn e David Brion Davis para examinar o controle europeu do mundo atlântico. ${ }^{15}$ Embora os estudiosos da história atlântica reconheçam que o número esmagador de pessoas que atravessou o atlântico antes de meados do século XIX veio da África e não da Europa, mais atenção deve ser dada ao fato de esta preponderância demográfica africana ter tido impacto significativo, especialmente em aspectos relacionados a resistência escrava, formação de comunidades e interações comerciais. Novas pesquisas devem questionar por que partes da África, pelo menos áreas muçulmanas, foram capazes de manter certo grau de autonomia diante do Atlântico Negro.

\footnotetext{
${ }^{14}$ GILROY, Paul. The Black Atlantic: modernity and double consciousness. Cambridge: Harvard University Press, 1993; BERLIN, Ira. From Creole to African: Atlantic Creoles and the origins of African-American society in Mainland North America. William \& Mary Quarterly, v. 53, n. 2, 1996; HALL, Gwendolyn Midlo. Slavery and African ethnicities in the Americas: restoring the links. Chapel Hill: University of North Carolina Press, 2005; LANDERS, Jane G. Atlantic Creoles in the age of revolutions. Cambridge, MA: Harvard University Press, 2010.

${ }^{15}$ BAILYN, Bernard. Atlantic history: concept and contours. Cambridge, MA: Harvard University Press, 2005; GREEN, Jack P.; MORGAN, Philip D. Atlantic history: a critical appraisal. Nova York: Oxford University Press, 2008.
} 


\section{Jihad e revolução na África Ocidental}

Os antecedentes do jihad na África Ocidental e o estabelecimento do Estado declaradamente muçulmano de Fuuta Bundu, perto dos campos de ouro de Bouré, no vale superior do rio Senegal, datam do final do século XVII. Posteriormente, rio abaixo, outro jihad resultou no estabelecimento de um segundo Estado muçulmano, que ficou conhecido como Fuuta Toro. Mais influente foi o estabelecimento de Fuuta Jallon, novamente através de jihad, e com a mesma conexão com os pastores fulbes, que também formavam a base dos jihad tanto em Fuuta Bundu e Fuuta Toro, conforme indicado no prefixo "Fuuta". Por volta de 1780, o Sudão Ocidental foi dominado pelos estados Fuuta muçulmanos, lançando as bases para a propagação do jihad ao lado do Sudáo Central e em outras partes do oeste posteriormente a 1800, especialmente com a fundação do Califado de Sokoto após 1804. Esse movimento do jihad era revolucionário, levando ao colapso estados estabelecidos e redesenhando o mapa político da África Ocidental. Como tal, foi uma resposta às injustiças e aos problemas do ancien régime dos senhores da guerra na África Ocidental e do comércio de escravos do mundo atlântico. A sobreposição na cronologia com a "era das revoluçôes" europeia requer uma reconsideração da natureza mutável da resistência escrava nas Américas como uma resposta aos desafios do ancien régime na Europa e à transformação das estruturas coloniais das Américas. ${ }^{16}$

${ }^{16}$ Por exemplo, ver os seguintes estudos: USMAN, Yusuf Bala (Ed.). Studies in the history of the Sokoto Caliphate. The Sokoto seminar papers. Lagos: Third Press International, 1979; BOBBOYI, H.; YAKUBU, A. M. (Ed.). The Sokoto Caliphate: history and legacies, 1804-2004. Kaduna: Arewa House, 2006. 2 v.; KANI, Ahmed M.; GANDI, K. A. (Ed.). State and society in the Sokoto Caliphate: essays in honour of sultan Ibrahim Dasuki. Sokoto: Usmanu Danfodiyo University, 1990; CHAFE, Kabiru S. The State and economy in the Sokoto Caliphate: policies and practices in the metropolitan districts, c. 1804-1903. Zaria: Ahmadu Bello University Press, 1999; MOUMOUNI, Seyni. Vie et oeuvre du cheik Uthmân Dan Fodio (1754-1817). De l'Islam au soufisme. Paris: L'Harmattan, 2008; BALOGUN, I. A. B. The life and works of 'Usman Dan Fodio. Lagos: Islamic Publications Bureau, 1975. Também ver o importante trabalho de Uthman Dan Fodio em BIVAR, A. D. H. The Wathiqat abl al-Sudan: a manifest of the Fulani jihad. Journal of African History, v. 2, n. 2, 1967. O jihad também tinha como alvo a prática do bori, resultando na deportação de muitos praticantes; ver MONTANA, Ismael Musah. The trans-Saharan slave trade of Ottoman Tunisia, 1574 to 1782. The Maghreb Review, v. 33, n. 2, p. 132-150, 2008; MONTANA, Ismael Musah. The ordeal of slave flights in Tunis. In: BELLAGAMBA, Alice; GREENE, Sandra; BROWN, Carolyn; KLEIN, Martin (Ed.). African slavery/ African voices. Nova York: Cambridge University Press, 2013; MONTANA, Ismael Musah. The Stambali of Tunis: its origins and transculturation from a secret-possession cult to ethno-religious and national culture in Husaynid Tunisia. In: TOLEDANO, Ehud R. (Ed.). African communities in Asia and the Mediterranean: identities between integration and conflict. Trenton, NJ: Africa World Press, 2011; MONTANA, Ismael Musah. Bori colonies in Tunis. In: MIRZAI, Behnaz; MONTANA, Ismael M.; LOVEJOY, Paul E. (Ed.). Slavery, Islam and diaspora. Trenton, NJ: Africa World Press, 2009; e MONTANA, Ismael Musah. Ahmad Ibn al-Qadi al-Timbuktawi on the Bori ceremonies of Sudan-Tunis. In: LOVEJOY, Paul E. (Ed.). Slavery on the frontiers of Islam. Princeton, NJ: Marcus Weiner Publishers, 2004. p. 173-198. 
Figura 1

Interior da enseada de Benin (c. 1785)

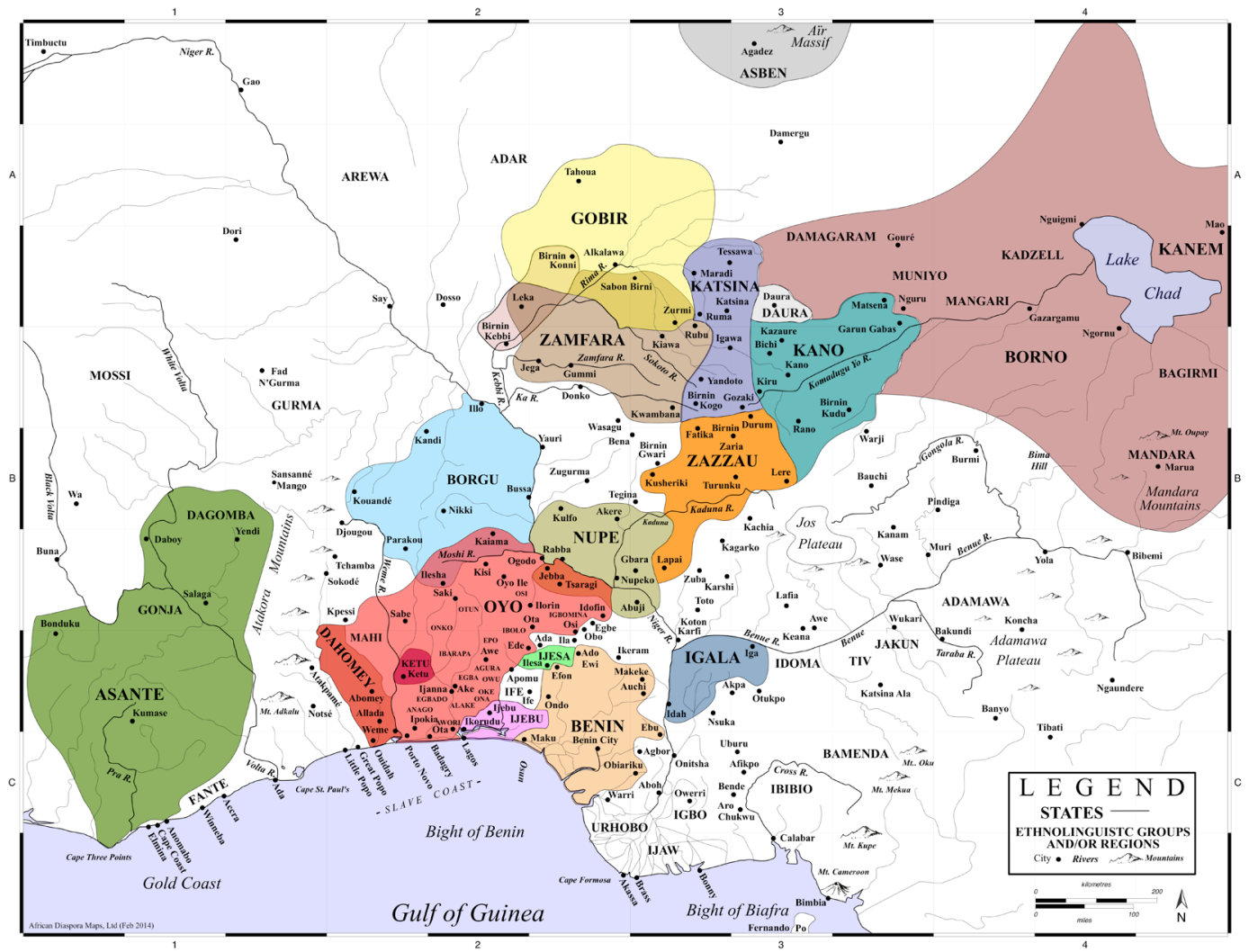

Fonte: LOVEJOY, Henry B. African diaspora maps Ltd. Disponível em: <www.africandiasporamaps.com>.

A origem do jihad na África Ocidental pode ser traçada a partir do colapso do império muçulmano de Songhai, em 1591-1592, e o período subsequente caraterizado pela decadência política e a consolidação de uma diáspora comercial e de centros de aprendizagem islâmica. A ideia de jihad e de mudanças políticas revolucionárias foi associada com a irmandade Qadiriyya, às famílias de clérigos kuntas, bem como com os fulbes, suas elites acadêmicas e religiosas. Estas haviam se espalhado por toda a savana e o Sahel da África Ocidental devido à migraçáo de transumância, uma vez que eram pastores de gado. A liderança intelectual muçulmana era aliada aos chefes de clás que detinham e geriam os rebanhos de gado que atravessavam a África Ocidental. Etnicamente relacionados, conhecidos como peul, ful, fulbe, fula, fulani, dependendo de sua localização na África Ocidental, esses grupos falam uma língua comum, o fula, além da elite intelectual também dominar o árabe graças aos estudos dos textos clássicos do Islá. 
Jihad na África Ocidental durante a "Era das Revoluçóes":

As consequências dos jihad são de conhecimento dos especialistas em história da África Ocidental, embora sua relevância para o mundo atlântico requeira um exame mais aprofundado. Como Murray Last observou, o jihad transformou a história da África Ocidental.

O movimento de reforma islâmica na África Ocidental deu origem ao maior Estado unitário africano no século XIX [ou seja, o Califado de Sokoto]. [O movimento] inspirou uma produção literária de grande quantidade e com maior aprendizagem do que qualquer outro movimento já visto ao sul do Saara. Ele [o movimento] estabeleceu as condiçóes para a geração de uma das economias indígenas mais produtivas na África Ocidental no final do século XIX. Na verdade, o movimento é tão central para a história da África Ocidental como é, por exemplo, a Revolução Francesa para a Europa. ${ }^{17}$

Como Last sugeriu, o tempo e a direção do pensamento reformista da África Ocidental correram em paralelo com o crescimento do radicalismo no mundo muçulmano, e no mundo cristão o período de 1775-1850 testemunhou revoltas e novas ideias no Império Otomano, na Europa e nas Américas. Segundo o autor, não há necessidade de "examinar as causas dessas mudanças e as maneiras pelas quais elas podem ter afetado a África Ocidental". ${ }^{18}$ Neste artigo, discuto como os acontecimentos da África Ocidental moldaram ou não os eventos na Europa e nas Américas. Definitivamente, a África deve ser incorporada nas interpretaçóes sobre o mundo atlântico durante a "era das revoluçóes".

Assim como a Revolução Francesa, como Last sugeriu, o jihad em Sokoto teve repercussóes no território que vai da Senegâmbia até o rio Nilo e o Mar Vermelho. A liderança de Sokoto forneceu inspiração intelectual e treinamento tático para os futuros jihadistas vinculados ao Estado de Sokoto. Umar al-Tall, originalmente de Fuuta Toro, estabeleceu-se em Sokoto depois de ter realizado a peregrinação a Meca e assumido o papel de líder espiritual e político dos membros da irmandade Tijaniyya. Casou-se com a filha de Muhammad Bello e tinha pretensôes à liderança suprema do Califado de Sokoto. Contudo, quando ele não foi selecionado após a morte de Bello, em 1837, abandonou Sokoto, regressando ao Sudão ocidental e dando início a um jihad sob a bandeira da Tijaniyya. ${ }^{19}$ A importância de Umar demonstra ainda que o triunvirato de Sokoto era parte de uma forte tradição de erudição influenciada pelos filósofos, cientistas políticos e intelectuais muçulmanos. $\mathrm{O}$ movimento mahdista também deve sua inspiração e muitos de seus primeiros adeptos ao Califado de

${ }^{17}$ LAST, Murray. Reform in West Africa: the jihad movements of the nineteenth century. In: AJAYI, J. F. Ade; CROWDER, Michael (Ed.). History of West Africa. 3. ed. Londres: Longman, 1987. v. 2, p. 1.

${ }^{18}$ Ibid.

${ }^{19} \mathrm{JAH}$, Omar. The effect of pilgrimage on the jihad of Al-Hajj 'Umar al-Futi 1794-1864. In: HASAN, Yusuf Fadl; DOORNBOS, Paul (Ed.). The central Bilad al Sudan: tradition and adaptation. Khartoum, 1977. p. 239. Também ver JAH, Omar. Al-Haj 'Umar's philosophy of jihad and its sufi basis. Tese (Ph.D.) - McGill University, Montreal, 1974. 
Sokoto, de onde vários adeptos haviam migrado em direção ao leste, na expectativa de encontrar com o Mahdi e testemunhar o fim do mundo e seu renascimento. Na verdade, Dan Fodio negou que ele fosse o Mahdi, apesar da crença de muitos, pois esperavam que o Mahdi aparecesse no início do século XIII da hijra, ou seja, no ano de 1884, ano em que Muhammad Ahmad se autoproclamou o Mahdi e estabeleceu Omdurman, na margem oposta do rio Nilo, instituindo a cidade de Cartum como sua capital.

\section{Figura 2:}

Califado Sokoto e estados vizinhos (c. 1850)

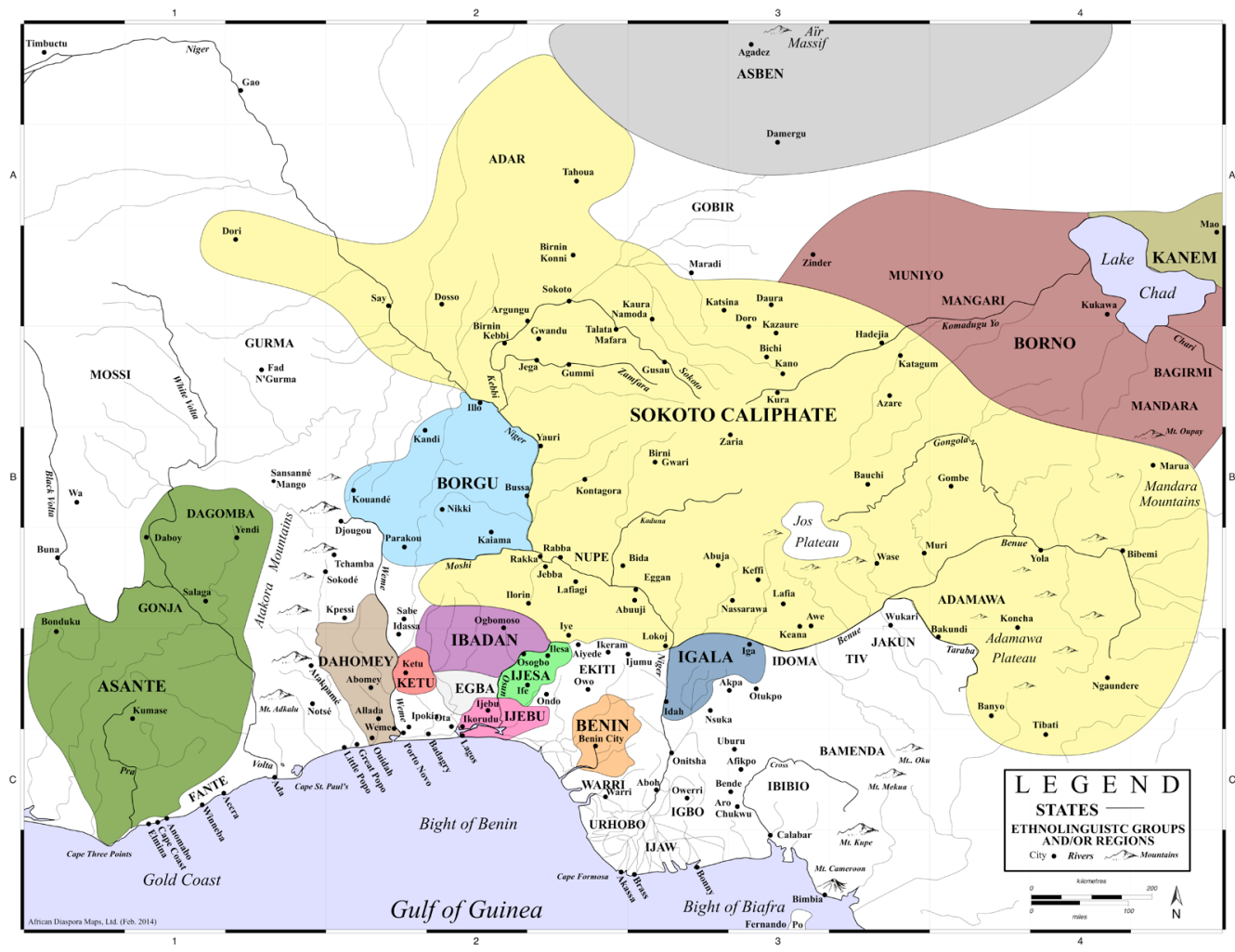

Fonte: LOVEJOY, Henry B. African diaspora maps Ltd. Disponível em: <www.africandiasporamaps.com>.

Tal como aconteceu durante a "era das revoluçôes" no mundo Atlântico e na Europa, na África Ocidental também houve antecedentes aos acontecimentos que vieram a ser concretizados no século XIX. Antes de se tornar o imã, o líder do jihad de Sokoto, Uthman Dan Fodio havia sido discípulo de Jibril ibn Umar, que na década de 1790 tinha defendido o jihad seguindo o modelo do extremo oeste do Sudáo, de onde muitos defensores do jihad no Sudão Central eram originários. Uthman Dan Fodio promoveu o jihad após 1804 e, com o apoio do seu irmão Abdullahi e de seu filho Muhammad Bello, tornou-se líder de um movimento revolucionário que atingiu os governos do Sudão Ocidental, da margem superior do rio Níger até o Lago Chade e o vale do Nilo. Jibril ibn Umar tinha sido um defensor 
JiHAd Na ÁFrica Ocidental durante a "Era das Revoluçốes":

em direçấo A UM Dí́logo com ERIC HobsbaWm e Eugene Genovese

Paul E. Lovejoy

do jihad contra os estados hausas e os clăs nômades dos tuaregues. No contexto da África Ocidental, seus nomes são tâo familiares para os estudiosos como os nomes de Karl Marx, Vladimir Lênin e León Trotsky são para a historiografia marxista, ou ainda os nomes de Eric Hobsbawm e Eugene Genovese para os estudos da era das revoluçôes e da resistência escrava. Juntos, o triunvirato de Sokoto escreveu mais de mil livros, panfletos e folhetos que incluíam poesia, textos jurídicos, exortaçôes e manuais de governança, em sua maioria escritos em árabe, mas incluindo alguns textos ajami, ou seja, em línguas hausa e fula com grafia árabe. ${ }^{20}$ Essa rica produção intelectual foi uma revoluçáo, merecendo ser comparada com a explosão literária do iluminismo. Como o mercado de livros do Sahel demonstra, estudiosos no oeste do Sudão liam e ainda leem obras do triunvirato de Sokoto, assim como a família Dan Fodio lia textos argelinos e do Songhai. ${ }^{21} \mathrm{O}$ nível e a profundidade teórica com que esse movimento buscava inspiração em textos islâmicos estão bem documentados e já foram submetidos à análise considerável, como refletido nas referências bibliográficas em árabe que foram compiladas por John Hunwick e seus colaboradores, com um vasto número de documentos em árabe assim como em outros idiomas utilizando os caracteres árabes (ajami). A maior prova dessa vasta coleção de documentos é a existência de várias bibliotecas em Timbuktu, que sobreviveram às ações revolucionárias de muçulmanos radicais no norte do Mali em 2012. O comércio de livros no Saara e no Sahel indica claramente o caráter intelectual do movimento jihadista, que, entre outros aspectos, envolvia um debate escrito assim

\footnotetext{
${ }^{20}$ De fato deve ser condiderada uma liderança de quatro, incluindo a única filha de Uthman Dan Fodio, Nana Asma'u (1793-1864), que escreveu extensivamente. Nana foi casada com Gidado Junaidu al-Bukhari, que tinha o título de Waziri, subordinado a Shehu. Conjuntamente com Muhammad Bello e 'Abdullahi, formavam a câmara interna da liderança governativa e militar, planejando a consolidação do Estado islâmico e a perpetuaçáo do estado permanente do jihad, que foi dirigido por cerca de 33 emirados e numerosos subemirados que constituíam o Califado. Gidaldo também escreveu extensivamente e sua biblioteca forneceu a documentação para estudo inicial do Califado de Sokoto realizado por LAST, Murray. The Sokoto Caliphate. Londres: Humanities Press, 1967. Ver ainda MACK, Beverly B.; BOYD, Jean. One woman's jihad: Nana Asma'u, scholar and scribe. Bloomington, IN: Indiana University Press, 2000; BOYD, Jean. Collected works of Nana Asma'u. Daughter of Usman 'dan Fodiyo (1793-1864). East Lansing, MI: Michigan State University Press, 2012; LAST, Murray. Reform movements in West Africa: the jihad movements of the nineteenth century. In: AJAYI, J. F. Ade; CROWDER, Michael (Ed.). History of West Africa. 3. ed. Londres: Longman, 1987. v. 2, p. 1-46; LAST, Murray. The Sokoto Caliphate and Borno. In: AJAYI, J. F. Ade. Unesco general history of Africa. v. 6, p. 555-599. Ver também BATRAN, A. The nineteenth-century Islamic revolutions in West Africa. In: AJAYI, J. F. Ade. Unesco general history of Africa. v. 6, p. 537-554; e HISKETT, Mervyn. The nineteenth-century jihads in West Africa. In: FAGE, J. D.; OLIVER, Roland (Ed.). The Cambridge history of Africa. Cambridge: Cambridge University Press, 1976. v. 5; ABUBAKAR, Sa'ad. The established caliphate: Sokoto, the emirates and their neighbors. In: IKIME, Obaro (Ed.). Groundwork of Nigerian history. Ibadan: Heinemann, 1980. p. 305-326; ABUBAKAR, Sa'ad. Borno in the nineteenth century. In: IKIME, Obaro (Ed.). Groundwork of Nigerian history. Ibadan: Heinemann, 1980. p. 327-346; ROBINSON, David. Revolutions in the Western Sudan. In: LEVTZION, Nehemia; POUWELS, Randall L. (Ed.). The history of Islam in West Africa. Athens, OH: Ohio University Press, 2000. p. 131-168.

${ }^{21}$ KRATLI, Graziano; LYDON, Gyslaine (Ed.). The trans-Saharan book trade: Arabic literacy, manuscript culture, and intellectual history in Islamic Africa. Leiden: Brill, 2011; e REESE, Scott (Ed.). The transmission of learning in Islamic Africa. Leiden: Brill, 2004.
} 
como na "era da revoluçôes" da Europa e das Américas. Os paralelos e contrastes entre os movimentos são muitos e já é tempo de incorporar o jihad como parte das "revoluçôes" que abalaram o mundo no último quartel do século XVIII e meados do século XIX.

Talvez não seja estranho que Hobsbawm e Genovese tenham ignorado acontecimentos de grande importância na África Ocidental. No entanto, não deveria ser assim, pois os intelectuais na década de 1960 estavam cientes desses acontecimentos e as transformaçôes que surgiram poderiam facilmente ter sido incorporadas em interpretaçôes mais amplas. ${ }^{22} \mathrm{O}$ estabelecimento de uma federação islâmica no começo do século XIX, que se estendia do moderno Burkina Fasso até a República Centro-Africana, era em si revolucionário. O Califado consistia de 33 emirados com duplas capitais em Sokoto e Gwandu e com a adiçấo de mais de vinte subemirados sob a liderança de Adamawa, também conhecido como Fombina, cuja capital estava em Yola, no rio Benue. Assim, o Califado se tornou o maior Estado da África desde o colapso de Songhai em 1591-1592. O modelo de governo islâmico foi inicialmente inspirado na irmandade sufi ou tariqa, chamada Qadiriyya. Em meados do século XIX, a inspiração veio da Tijaniyya, e no final do mesmo século, da irmandade da Mahdiyya. Esse modelo de estado e de revoluçáo contrasta nitidamente com o republicanismo que caracterizou a "era das revoluçóes" estudada por Hobsbawm e outros.

\section{O surgimento do Califado de Sokoto}

A centralidade de Sokoto no movimento do jihad é indiscutível. No processo de criação de um Estado islâmico, todos os governos hausas foram derrubados, o império de Oyó entrou em colapso e Borno perdeu metade de seu território. Como é evidente a partir de mapas da África Ocidental datados de 1780 e 1850, a transformaçáo foi verdadeiramente revolucionária (figura 1 e figura 2). O jihad foi baseado na fidelidade à etnia fulbe conhecida em haussa como fulani e, portanto, estendeu o seu apelo aos estados Fuuta no oeste do Sudão. O clã do Shehu era sulleibawa, associado a uma tradição intelectual, estilo de vida sedentário e ambiente multilinguístico. Os Dan Fodio, por exemplo, falavam hausa, fula, árabe e, provavelmente, kanuri e tamachek, embora aparentemente não falassem o iorubá. Mesmo em lugares tão distantes como o centro do vale do rio Níger havia uma identificação inicial com Sokoto, principalmente após a fundação de Hamdullahi, localizado ao sul de Timbuktu, na regiáo de Macina. Ahmad Muhammad Lobbo al-Masini iniciou uma jihad na região do Níger em 1816 e se aliou a Uthman Dan Fodio, aliança à qual ele renunciou

${ }^{22}$ Tão cedo quanto HODGKIN, Thomas (Ed.). Nigerian perspectives: an historical anthology. Londres: Oxford University Press, 1960; e especialmente SMITH, H. F. C. [Abdullahi]. A neglected theme of West African history: the Islamic revolutions of the $19^{\text {th }}$ century. Journal of the Historical Society of Nigeria, v. 2, n. 2, 1961. Posteriormente, houve uma expansão do conhecimento acerca do jihad e sua liderança, que em parte aparece nas notas deste trabalho. 
com a morte de Uthman em 1817. Posteriormente, Hamdullahi passou a ser um Estado jihadista independente até quando foi derrubado por al-Hajj 'Umar. Tivesse Hamdullahi permanecido parte de Sokoto, o Califado teria se estendido de Bamako ao lago Chade, ou mesmo a uma área maior, visto que Sokoto reivindicou a costa da baía de Benin. Ainda assim, as conquistas militares subsequentes dos estados Bambara de Segu e Kaarta empreendidas por al-Hajj 'Umar só foram possíveis com o auxílio de tropas recrutadas no Califado de Sokoto e em outros Estados jihadistas. A conquista de Hamdullahi resultou na criação do Califado de Tijaniyya. A resistência à ocupação francesa liderada por Samori Ture em 1879 e a revolta Mahadista no Sudão nilótico em 1884 devem ser interpretadas como reflexos que, de certa forma, se estendem aos tempos contemporâneos com o movimento jihadista do Boco Haram no norte da Nigéria.

O movimento do jihad fornece o contexto para analisar como a mudança política na África Ocidental refletiu no mundo atlântico. Acusaçôes de que as autoridades políticas estavam envolvidas no que foi considerado escravização ilegal eram uma das reivindicações de legitimação para a necessidade do jihad. As queixas chegaram a um ápice em 1804, quando o governo de Gobir ordenou a apreensão de seguidores de 'Abd al-Salam, um dos discípulos mais fervorosos do Uthman Dan Fodio, desafiando diretamente a liberdade dos seguidores de Uthman. Alegou-se que muitos dos que foram apreendidos eram escravos fugidos dos seus proprietários. Porém, a partir da perspectiva dos jihadistas, os seguidores de al-Salam eram muçulmanos, portanto livres, embora seja impossível verificar o status e origem de cada indivíduo. A linha tênue entre as reivindicaçôes de liberdade com base na adesão ao Islã e os livres por nascimento foi interpretada em benefício do requerente; ou seja, era da responsabilidade de senhores de escravos apresentar provas de que seus escravos não eram muçulmanos. Como a literatura acadêmica sobre o movimento do jihad deixa claro, a escravidão era um fator constante em discussóes sobre religião e ideologia, e que permeou os padrões de resistência e de reformas políticas. Quando o jihad foi declarado em 1804, Uthman Dan Fodio certamente não estava ciente de eventos específicos no Caribe e provavelmente desconhecia que o Haiti havia se tornado um Estado independente naquele mesmo ano. No entanto, houve grande preocupação no interior da liderança política e intelectual muçulmana com o fato de que muçulmanos escravizados estavam sendo vendidos aos europeus através de Oyó. Devido ao comércio francês em Porto Novo, alguns desses muçulmanos escravizados podem ter sido enviados a Sáo Domingos.

A escravização de muçulmanos livres e sua venda aos cristãos envolvidos no comércio atlântico foram de particular interesse para Muhammad Bello. Bello condenou a venda de escravos para Oyó, claramente articulado em seu manifesto Infaq al-Maysur, concluído em 1812. ${ }^{23}$ A preocupação com a escravização ilegal de muçulmanos foi claramente expressa

\footnotetext{
${ }^{23}$ BELLO, Muhammad. Infāq al-Maysūr fì tārìkh bilād at-Takrūr [1812]. Edição de Bahija Chadli. Rabat: Institute of African Studies, 1996. p. 69-72, conforme tradução de Yacine Daddi Addoun. Também ver
} 
JiHAd Na ÁFrica Ocidental durante a "Era das Revoluçốes":

em direção a um diálogo com ERIC HobsbaWm e Eugene Genovese

Paul E. Lovejoy

no debate entre Muhammad Bello e Shehu Muhammad al-Kanemi de Borno, como apresentado na Infaq al-Maysur, e continuou em uma correspondência contínua entre os dois governantes por mais uma década, resultando em guerra entre os estados de Sokoto e Borno em 1826-1827. O debate sobre o aspecto legal da escravização de muçulmanos não se estendeu para um debate sobre a natureza da instituição da escravização em si. As questóes que Bello e al-Kanemi abordaram estavam relacionadas com a lei islâmica e a regulamentação da instituição da escravidão. Muito diferente das questóes por trás da resistência à escravidão nas Américas que contestavam a instituição escravista, a preocupação no Califado de Sokoto estava voltada para a natureza do Estado muçulmano e o papel do mesmo na proteção de muçulmanos livres. O jihad rapidamente derrubou os principais governantes hausas de Gobir, Kebbi, Kano, Katsina, Zaria e, por volta de 1808, se espalhou em direção ao leste para Borno e em 1810 para o sul, em direção a Nupe. A partir do Sudão Central, o movimento jihadista se expandiu em ondas e, após 1817, para o sul em Oyó e na Iorubalândia, ganhando força com a formação do emirado de Ilorin no Califado de Sokoto em $1823 .{ }^{24}$ A questão do escravo/status livre preocupou o jihad uma vez que a campanha foi estendida para Borno após 1808, Nupe em 1810 e Oyó depois da revolta em Ilorin em 1817, que levou ao colapso de Oyó entre 1823 e 1836 e o crescimento da diáspora iorubá no Brasil, Cuba e Serra Leoa.

BELLO, Muhammad. Infaq al-Maisur [1812]. In: ARNETT, E. J. The rise of the Sokoto Fulani. Kano, 1929. Também ver QUADRI, Y. A. An appraisal of Muhammad Bello's Infaqul-maysur ft tarikhi bilad t-Takrur. Journal of Arabic and Religious Studies, n. 3, p. 53-62, 1986.

${ }^{24}$ Acerca de Borno, ver ALKALI, Muhammad N. El-Kanemi's Response to the Extension of Shaykh 'Uthman Dan Fodio's Jihad Against Borno. In: BOBBOYI, H.; YAKUBU, A. M. (Ed.). The Sokoto Caliphate, op. cit. v. 1, p. 231-239; e BRENNER, Louis. The Jihad debate between Sokoto and Borno: an historical analysis of Islamic political discourse in Nigeria. In: AJAYI, J. F. Ade; PEEL, J. D. Y. (Ed.). People and empires in African history: essays in memory of Michael Crowder. Londres: Longman, 1992. p. 21-43; BRENNER, Louis. The Shehus of Kukawa: a history of the Al-Kanemi dynasty of Bornu. Oxford: Clarendon Press, 1973. Para informaçôes sobre Nupe, ver KOLAPO, Femi James. Military turbulence, population displacement and commerce on a slaving frontier of the Sokoto Caliphate: Nupe c. 1810-1857. Tese (Ph.D.) - York University, Toronto, 1999; KOLAPO, Femi James. Ethnicity and identity at the Niger-Benue during the 19th-century Nupe jihad. In: OJO, Olatunji; HUNT, Nadine (Ed.). Slavery in Africa and the Caribbean: a history of enslavement and identity since the 18th century. Nova York: I. B. Tauris, 2012. p. 9-37; KOLAPO, Femi James. Niger river trade and the interregnum at Aboh, 1844-1862. In: BROWN, Caroline A.; LOVEJOY, Paul E. (Ed.). Repercussions of the Atlantic slave trade: the interior of the Bight of Biafra and the African diaspora. Trenton, NJ: Africa World Press, 2011. p. 205-220; KOLAPO, Femi James. The dynamics of early $19^{\text {th }}$ century Nupe wars. Scientia Militaria. South Africa African Journal of Military Studies, v. 31, n. 2, p. 1-35, 2003; MASON, Michael. The Nupe Kingdom in the nineteenth century: a political history. Tese (Ph.D.) - University of Birmingham, Birmingham, 1970; MASON, Michael. The foundations of the Bida Kingdom. Zaria: Ahmadu Bello University Press, 1979. MASON, Michael. The Jihad in the South: an outline of nineteenth century Nupe hegemony in North-eastern Yorubaland and Afenmai. Journal of the Historical Society of Nigeria, v. 5, n. 2, 1970; MASON, Michael. Population and "slave raiding" - the case of the middle belt of Nigeria. Journal of African History, v. 10, n. 4, p. 551-564, 1969; MOHAMMED, A. R. The Sokoto jihad and its impact on the confluence area and Afenmai. In: USMAN, Y. B. (Ed.). Studies in the history of the Sokoto Caliphate, op. cit.; e OBAYEMI, Ade. The Sokoto jihad and the O-kun Yoruba: a review. Journal of the Historical Society of Nigeria, v. 9, n. 2, p. 61-87, 1978. 
JiHAd Na ÁFrica Ocidental durante a "Era das Revoluçốes":

em direçấo A UM Dí́logo com ERIC Hobsbawm e Eugene Genovese

Paul E. Lovejoy

A morte de Uthman Dan Fodio em 1817 desencadeou tensóes dentro do movimento do jihad relacionado à etnia, interpretaçôes da tradição jurídica e questóes de confiança na liderança, desencadeando uma crise de sucessão que foi resolvida mediante o estabelecimento de um Califado sob a liderança dual do irmão de Uthman, Abdullahi, centrado em Gwandu, e seu filho, Muhammad Bello, centrado em Sokoto. A decisão da liderança do emirado de Hamdullahi de distanciar-se politicamente de Gwandu e de Sokoto reflete a insatisfaçáo com esse compromisso político. A revolta e execução de Abd es-Salaam em Zamfara ia de encontro à percepção pública de que o jihad era especificamente um movimento muçulmano não associado à etnia, pois a execuçáo de Abd es-Salaam foi vista como motivada pela sua etnia hausa, enquanto o restante da liderança dos principais emirados e do próprio Sokoto era etnicamente fulbe ou em língua hausa fulani. ${ }^{25} \mathrm{Abd}$ es-Salaam era originário de Zamfa-

${ }^{25}$ A produção acadêmica acerca do Califado de Sokoto é extensiva. Além de LAST, Murray. The Sokoto Caliphate, op. cit.; LAST, Murray. Reform movements in West Africa, op. cit. p. 1-46; LAST, Murray. The Sokoto Caliphate and Borno, op. cit. v. 6, p. 555-599; e BATRAN, A. The nineteenth-century Islamic revolutions in West Africa, op. cit. v. 6, p. 537-554, ver especialmente USMAN, Y. B. ed. Studies in the history of the Sokoto Caliphate, op. cit., principalmente ABBA, Yusufu. The 1804 jihad in Hausaland as a revolution. p. 20-33; USMAN, Y. B. The transformation of political communities: some notes on a significant dimension of the Sokoto jihad. p. 34-58; LAVERS, John E. The diplomatic relations of the Sokoto Caliphate: some thoughts and a plea. p. 379-391; HAMANI, Djibo. Adar, the Toureg and Sokoto: relations of Sokoto with the Hausawa and Toureg during the nineteenth century. p. 392-407; MUHAMMAD AL-BUKHARI, Junaidu b. A contribution to the Biography of the Shaykh Usman mentioning the various places where he lived. p. 463-472; BALOGUN, I. A. B. Uthman Dan Fodio: the mujaddid of West Africa. p. 473-492. Também ver BOBBOYI, H.; YAKUBU, A. M. (Ed.). The Sokoto Caliphate, op. cit., especialmente BUGAJE, Usman M. Scholarship and revolution: the impact of a tradition of Tajdid on the Sokoto Caliphal leaders. v. 2, p. 11-21; GWANDU, Abubakar. The vision and mission of Shaykh Abdullahi Fodio. In: BOBBOYI, H.; YAKUBU, A. M. (Ed.). The Sokoto Caliphate, op. cit. v. 2, p. 23-39; ABU-MANGA, Al-Amin. The role of the "pen" in the establishment and consolidation of the Sokoto Caliphate. v. 2, p. 40-52; TUKUR, Mahmud M. The teachings of the Sokoto Caliphate. v. 2, p. 53-80; ADO-KURAWA, Ibrahim. The jihad and the consolidation of Sudanic intellectual tradition. v. 2, p. 81-99; ABDULKADIR, Mohammed S. The effects of the extension of the Sokoto Caliphate on the Igala Kingdom. v. 1, p. 53-65; LAST, Murray. Innovation in the Sokoto Caliphate. v. 2, p. 328-347. Ver também KANI, Ahmed M.; GANDI, K. A. (Ed.). State and society in the Sokoto Caliphate, op. cit., incluindo BALOGUN, I. A. B. Shaikh Uthman Danfodiyo: founder of the Sokoto heritage. p. 207-222; MOHAMMED, A. R. The Sokoto jihad and its impact on the confluence area and Afenmai. p. 142-157; SULAIMAN, Ibrahim. Towards a vision of the Future: a letter from sultan Muhammad Bello to the muslim Ummah in Nigeria. v. 2, p. 396-408. Ver ainda ABBA, A. The establishment of Gombe Emirate, 1804-1882. v. 1, p. 11-30. A bibliografia é bem mais ampla; ver KANI, Ahmed M. The intellectual origin of the Sokoto Caliphate. Ibadan, 1984; BUGAJE, U. M. The tradition of Tajdid in Western Bilad al-Sudan: a study of the genesis, development and patterns of Islamic revivalism in the region, 9901900 AD. Tese (Ph.D.) — Universidade de Cartum, Cartum, 1991; ZAHRADEEN, M.S. Abdullahi Ibn Fodio's contribution to the Fulani jihad in the $19^{\text {th }}$ century hausaland. Tese (Ph.D.) - McGill University, Montreal, 1976; BELLO, O. The political thought of Muhammad Bello (1781-1837) as revealed in his Arabic writings, more especially al-Ghayth al-wabl fi sirat al-imam al-adl. Tese (Ph.D.) - University of London, Londres, 1983; omoiya, S.Y. Diplomacy as veritable instrument of war: a study of Ilorin wars of survival as an emirate. Ilorin Journal of History, v. 1. n. 2, p. 73-85, 2006; MOUMOUNI, Seyni. Vie et oeuvre du cheik Uthmân Dan Fodio, op. cit.; HUNWICK, John (Ed.). The writings of Central Sudanic Africa. Leiden: E. J. Brill, 1995; BARKINDO, B. M. (Ed.). Studies in the history of Kano. Ibadan: Heinemman, 1983; MINNA, M. T. M. Sultan Muhammad Bello and his intellectual contribution to the Sokoto Caliphate. Dissertação 
Jihad na África Ocidental durante a "Era das Revoluçóes":

ra e foi atacado por Yunfa, rei de Gobir, que iniciou a jihad em 1804. Ele era essencialmente o único clérigo não fulbe (fulani) subordinado a Utman Dan Fodio, se rebelando com sua morte em 1817.

A revolta simultânea de muçulmanos dentro das forças armadas em Ilorin introduziu um novo fator, exacerbando o fato de que o jihad combinava elementos de identidade étnica e religiosa. A instabilidade política associada a questóes de sucessão levou à independência de Macima, o emirado localizado mais a oeste, e o eventual estabelecimento do Califado de Hamdullahi. ${ }^{26}$ A crise de 1817 foi resolvida por meio de uma estratégia de governo dualista e da expansão do jihad sob a bandeira da irmandade da Qadiriyya com a liderança étnica dos fulani. A chegada ao poder de Alimi Saleh em Ilorin facilitou o reconhecimento desse Estado como um emirado em 1823. Alimi Saleh era um clérigo fulani de Ilorin responsável pela formação de uma coalisão muçulmana que derrubou Kakamfo Afonjá do poder. Abd es-Salaam de Zamfara, executado em 1817, não tinha conexão com o filho de Saleh, também chamado Abd es-Salaam, que era clérigo em Oyó e era de origem fulbe ou fulani, não hausa. Esse último se tornou o primeiro emir de Ilorin em 1823, quando Ilorin foi reconhecido como um emirado do Califado de Sokoto; seu pai morreu no mesmo ano. Ele era subordinado a Abdullahi Dan Fodio em Gwandu, não a Muhammad Bello em Sokoto. Foi o auxílio militar de Gwandu que o ajudou a se manter no poder em Ilorin.

A tentativa de identificação de muçulmanos de acordo com sua filiação étnica é confusa. Muçulmanos de origem iorubá, hausa e kanuri estavam forjando alianças que resultariam na supremacia muçulmana no interior do Estado de Oyó, enquanto o Daomé consolidava sua independência dando início ao colapso final de Oyó e a emigração em massa de refugiados para o sul — Ibadan, Abeokuta e em outros lugares, com o objetivo de distanciarem-se do Islâ. ${ }^{27}$ Quando da morte de Muhammad Bello, em 1837, Ilorin controlava com êxito o nordeste do território iorubá sob a liderança fulani, enquanto Nupe tinha sido dividido em vários emirados novamente sob a liderança fulani. Emirados adicionais foram criados no sudeste do território hausa do jihad em Bauchi, Gombe e Adamawa, que também tiveram liderança fulani.

(Ph.D.) - University of London, Londres, 1982; SA'ID, Halil Ibrahim. Revolution and reaction: The Fulani jihad in Kano and its aftermath 1807-1919. Dissertação (Ph.D.) - University of Michigan, Ann Arbor, 1978; e Balogun, The life and works of 'Usman Dan Fodio, op. cit.

${ }^{26}$ BROWN, William O. The Caliphate of Hamdullahi, c. 1818-1864. Tese (Ph.D.) - University of Wisconsin, Madison, 1969; STEWART, Charles C. Diplomatic relations in early $19^{\text {th }}$ century West Africa: Sokoto-Masina-Azaouad correspondence. In: USMAN, Yusuf Bala (Ed.). Studies in the history of the Sokoto Caliphate, op. cit. p. 408-429.

${ }^{27}$ LAW, Robin. The Oyo-Dahomey wars, 1726-1823: a military analysis. In: FALOLA, Toyin; LAW, Robin (Ed.). Warfare and diplomacy in precolonial Nigeria. Madison, WI: African Studies Program, 1992. p. 9-25. 
O impacto do jihad resultou no completo abandono dos bairros ao redor de Katunga, capital de Oyó, devido à fuga e à expansão da escravidão. A região, anteriormente densamente povoada, foi abandonada, situação que permanece até os dias atuais. Muitas vezes referidos como guerras iorubás na historiografia, e às vezes caracterizadas como guerra civil, os conflitos que levaram à incorporação de Ilorin ao Califado de Sokoto foram mais do que um distúrbio civil. Esses conflitos foram responsáveis pelo colapso do Estado de Oyó e a subsequente guerra que provocou escravização em massa, cujas vítimas foram enviadas a Cuba, Brasil, Trinidade e Serra Leoa e passaram a fazer parte da diáspora iorubá. Assim, a presença e as açóes dos iorubás na diáspora têm de ser consideradas como consequência dos jihad na África Ocidental. O envolvimento em eventos nas Américas foi mais do que uma extensão da resistência escrava associada à "era das revoluçôes", como descrito por estudiosos influenciados pela tradição inaugurada por Hobsbawm e Genovese, a exemplo dos historiadores Jane Landers, Matt Childs e Joáo Reis. ${ }^{28}$ Como podemos compreender como os africanos na diáspora pensavam sobre seu envolvimento nesses eventos se não levarmos em consideração suas experiências prévias? As complexidades inerentes à identidade étnica $\mathrm{e}$ aos conflitos religiosos influenciam como nós interpretamos o levante malê na Bahia, assim como a resistência iorubá em Cuba e a agitação muçulmana em Serra Leoa, particularmente na década de 1830 .

A revolta em Ilorin em 1817 teve um significado especial ao conectar o movimento do jihad com a "era das revoluçôes". O levante em Ilorin teve início uma década após a turbulência revolucionária que resultou no estabelecimento do Califado de Sokoto, inicialmente como uma revolta de escravos muçulmanos alistados no serviço militar do Estado de Oyó. A transição desse levante inicial de escravos com um caráter militar em jihad, assim como a incorporação de Ilorin ao Califado de Sokoto em 1823 precipitaram o colapso de Oyó, o principal governo no interior do golfo de Benin. Oyó controlava uma parte extensa da Iorubalândia, que ia do litoral, incluindo Porto Novo e Badagri, o território do Daomé, e o porto de Ouidah, chegando às terras do território Mahi e regióes do Borgu. Porém seu território foi constantemente reduzido até o abandono do distrito nas proximidades da capital Katunga, em 1836. O jihad alterou o mapa político do interior da África Ocidental, não só a região da Iorubalândia, como também a região ao longo do rio Níger, na década de 1820 , até a região ao redor do lago Chade. Em última análise, os jihad transformaram o interior da África Ocidental até o Sudão moderno e o vale do rio Nilo. Em termos geográficos e demográficos, o movimento do jihad associado à fraternidade Qadiriyya pode ser comparado às mudanças revolucionárias do mundo atlântico. Apesar de sua importância, esse movimento foi praticamente ignorado pelos estudiosos da "era das revoluçôes" e, de fato, é

\footnotetext{
${ }^{28}$ Ver, por exemplo: LANDERS, Jane G. Atlantic Creoles in the age of revolutions, op. cit.; CHILDS, Matt D. The 1812 aponte rebellion in Cuba and the struggle against Atlantic slavery. Chapel Hill, NC: University of North Carolina Press, 2009; REIS, João José. Slave rebellion in Brazil e a edição revista e ampliada, Rebelião escrava no Brasil.
} 
JiHAd Na ÁFrica Ocidental durante a "Era das Revoluçốes":

em direçấo A UM Dí́logo com ERIC HobsbaWm e Eugene GENOVESe

Paul E. Lovejoy

completamente desconhecido para muitos especialistas que lidam com a resistência escrava e a escravidão e mesmo aqueles que estudam a diáspora iorubá nas Américas. ${ }^{29}$

A cronologia dos jihad coincide com os eventos da "era das revoluçôes". O movimento jihadista teve início com a fundação dos Estados de Fuuta Bundu e Fuuta Toro na Senegâmbia e ganhou impulso após a consolidação dos Fuuta Jallon, c. 1780 e, posteriormente, com o jihad em Sokoto. Em Sokoto, o movimento teve início em 1804 e continuou até o colapso de Oyó em 1836 e a morte de Muhammad Bello, em 1837. A figura de al-Hajj 'Umar e suas açôes no oeste do Sudão ajudaram a estender geograficamente os jihad, agora sob a ban-

${ }^{29}$ A literatura sobre o jihad e especificamente acerca da queda de Oyó apresenta uma imagem controversa. A
centralidade do jihad nos eventos das décadas de 1810, 1820 e 1830 tem sido demonstrada por especialistas de
Ilorin, tais como I. O. Akinjogbin, Peter Morton-Williams, J. A. Atanda e Hakeem Danmole. Especialistas
na história iorubá, tais como Jacob Ajayi, Robert Smith, Toyin Falola, Robin Law e John Peel, também
reconhecem o fator islâmico. Ver AKINJOGBIN, I. A. Prelude to the Yoruba Civil Wars of the nineteenth
century. Odu, v. 1, n. 2, p. 34-46, 1965; AKINJOGBIN, I. A. A chronology of Yoruba history, 1789-1840. $O d u$, v. 2, n. 2, p. 81-86, 1966; LAW, Robin. The chronology of Yoruba wars of the early nineteenth century: a reconstruction. Journal of the Historical Society of Nigeria, v. 5, p. 211-222, 1970; MORTON-WILLIAMS, Peter. The Fulani penetration into Nupe and Yorubaland in the nineteenth century. In: LEWIS, I. M. (Ed.). History and social anthropology. Londres, 1968. p. 1-24; GBADAMOSI, T. G. O. The growth of Islam among the Yoruba 1841-1908. Atlantic Highlands, NJ: Humanities Press, 1978. cap. 1; FALOLA, Toyin. The impact of the nineteenth-century Sokoto jihad on Yorubaland. In: KANI, Ahmed M.; GANDI, K. A. (Ed.). State and society in the Sokoto Caliphate, op. cit. p. 126-141; ATANDA, J. A. The fall of the old Oyo Empire: a reconsideration of its cause. Journal of the Historical Society of Nigeria, v. 5, p. 477-490, 1971; ATANDA, J. A. The Yoruba wars and the collapse of the old Oyo Empire. In: FALOLA, Toyin (Ed.). Yoruba historiography. Madison, WI: African Studies Program, 1991. p. 105-121; DANMOLE, Hakeem Olumide Akanni. The frontier emirate: a history of Islam in Ilorin. Tese (Ph.D.) - University of Birmingham, Birmingham, 1980); DANMOLE, Hakeem Olumide Akanni. Samuel Johnson and the history of Ilorin. In: FALOLA, Toyin (Ed.). Pioneer, patriot and patriarch. Samuel Johnson and the Yoruba people. Madison: African Studies Program, 1993. p. 139-49; DANMOLE, Hakeem Olumide Akanni. Emirate of the 'Yarba': Ilorin in the nineteenth century. In: BOBBOYI, H.; YAKUBU, A. M. (Ed.). The Sokoto Caliphate, op. cit. v. 1, p. 31-52; O'HEAR, Ann. Samuel Johnson and the Dramatis personae of early nineteenth-century Ilorin. In: FALOLA, Toyin (Ed.). Pioneer, patriot and patriarch, op. cit. p. 151-161. Ver tambêm O'HEAR, Ann. Power relations in Nigeria: Ilorin slaves and their successors. Rochester, NY: University of Rochester Press, 1997. Ver ainda LOCKHART, Jamie Bruce; LOVEJOY, Paul E. (Ed.). Hugh Clapperton into the interior of Africa: records of the second expedition 1825-1827. Leiden: Brill, 2005. Enquanto o jihad é um fator importante no trabalho seminal de LAW, Robin. The Oyo Empire, c. 1600 - c. 1836: a West African imperialism in the era of the Atlantic slave trade. Oxford: Clarendon, 1977; ele não argumenta em favor de uma influência dominante durante esse período. Ver: LAW, Robin. The chronology of the Yoruba wars of the early nineteenth century: a reconsideration, op. cit. p. 211-222; LAW, Robin. The Owu war in Yoruba history. Journal of the Historical Society of Nigeria, v. 7, n. 1, p. 141-147, 1973; LAW, Robin. Making sense of a traditional narrative: political disintegration in the Kingdom of Oyo. Cahiers d'Études Africaines, v. 22, p. 387-401, 1982. De modo semelhante, J. D. Y. Peel defende a centralidade do Islã na construção da identidade iorubá no século XIX, mas não explora o movimento do jihad como um fenômeno decisivo naquele desenvolvimento. Ver: PEEL, J. D. Y. Religious encounter and the making of the Yoruba. Bloomington: Indiana University Press, 2000. Em contrapartida, o jihad é visto como um fator central em minha análise na coleção editada por Falola e Childs, Yoruba diaspora in the Atlantic World. Ver também FALOLA, Toyin (Ed.). Yoruba historiography, op. cit.; OBAYEMI, Ade. History, culture, Yoruba and northern factors. In: OLUSANYA, G. O. (Ed.). Studies in Yoruba history and culture. Ibadan: University of Ibadan Press, 1983. p. 72-87. 
deira da irmandade da Tijaniyya, ao invés do controle da Qadiriyya que carateriza os jihad anteriores. Ou seja, o movimento do jihad e a "era das revoluçôes" foram contemporâneos, apesar de alguns autores ressaltarem períodos distintos.

O quadro cronológico da "era das revoluçóes" muda de estudioso para estudioso; Hobsbawm, por exemplo, enfatizou os anos 1789-1848; Wim Klooster usa a independência dos Estados Unidos como o momento fundador das chamadas "guerras civis" no império britânico. Para David Brion Davis, a era das revoluçóes começa na década de 1770 e termina em 1823. Jane Landers associa a "era das revoluçôes" aos movimentos de resistência à escravidão que tiveram lugar a partir da segunda metade do século XVIII até meados do século XIX. ${ }^{30}$ Logo, as datas limites da "era das revoluçôes" dependem do foco de análise, porém os autores concordam que o período afetou a bacia do Atlântico. Os jihad se encaixam nessa cronologia, tendo se iniciado na década de 1770 e concluído em 1860. Durante essa era, praticamente todo o interior da África Ocidental, da Senegâmbia ao Lago Chade, caiu sob domínio de estados jihadistas, que eliminaram as estruturas políticas anteriores com resultados bastante significativos, apesar de diferentes, e que ajudam a expandir o conceito de mundo atlântico de modo a incluir a África Ocidental.

\section{África Ocidental islâmica e o tráfico de escravos no Atlântico}

As relaçôes entre as populações muçulmanas e o mundo atlântico podem ser divididas em duas fases marcadas por rupturas nos padróes comerciais e sociais. O primeiro período cobre o século XVIII enquanto o segundo corresponde à consolidação do Califado de Sokoto, após 1804. Jihad ocorreram em ambos os períodos, mas, durante o século XVIII, sua influência esteve confinada ao território a oeste do Sudáo. Durante o segundo período, a fundação de Sokoto como capital de um Estado islâmico no Sudáo Central marcou uma mudança no comércio, principalmente com relação à política de deportação de escravos para as Américas. Os estágios de envolvimento no tráfico de escravos afetaram tanto os setores transatlânticos como transaarianos, reforçando simultaneamente o comércio dentro do mundo muçulmano. Apesar disso, a presença muçulmana nas Américas é reconhecida tanto no período anterior como posterior a 1804 . O segundo período é caracterizado pela expansão e consolidação do jihad no interior e pela campanha britânica para abolir o comércio de escravos. A pressão naval britânica, inicialmente concentrada no comércio ao longo da costa ocidental africana, reforçou os objetivos políticos dos estados muçulmanos do interior, ou seja, limitar o envolvimento no tráfico transatlântico de escravos. Os jihad aliados

\footnotetext{
${ }^{30}$ KLOOSTER, Wim. Revolutions in the Atlantic world: a comparative history (Nova York: New York University Press, 2009); DAVIS, David Brion. The problem of slavery in the age of revolution, 1770-1823. Ithaca, NY: Cornell University Press, 1975; LANDERS, Jane G. Atlantic Creoles in the age of revolutions, op. cit.
} 
à abolição britânica favoreceram a expansão do comércio de escravos na região da África Centro-Ocidental, a regiáo Congo-Angola, de maioria falante de línguas bantus. Metade de todos os africanos deportados para as Américas era originária dessa região. Principalmente após 1807 , dois terços de todos os africanos deportados embarcaram nessa região, enquanto $12 \%$ embarcaram em navios no golfo do Benin, dos quais nem todos teriam sido iorubás ou muçulmanos.

A origem da população escravizada na África deve ser contextualizada, assim como o destino dos escravos determinou as sociedades escravistas formadas nas Américas. Contextos específicos moldaram o movimento de africanos escravizados, apesar da influência de forças globais. Teoricamente, em termos demográficos, eu argumento que a África Ocidental poderia ter fornecido todos os escravos que foram enviados para as Américas durante a "era das revoluçôes". Apesar da possibilidade, isso nâo aconteceu. Designaçôes utilizadas no banco de dados Slave voyages fazem pouco sentido para a geografia política da África durante os séculos XVIII e XIX. ${ }^{31}$ No período que nos interessa, eu dividiria a África Ocidental entre áreas dominadas pelos Estados jihadistas, por um lado, e os vários estados costeiros, localizados entre a costa da Guiné até a baía de Biafra, por outro. A Senegâmbia a que se refere o banco de dados Slave voyages corresponde aos estados de Fuuta Toro, Fuuta Bundu e Kaarta. "Serra Leoa" refere-se não apenas ao rio do mesmo nome, mas também à região sob controle do Fuuta Jallon e das redes comerciais muçulmano-diulas. A Costa do Ouro refere-se ao território ocupado pelo Estado de Ashante, a regiáo Akan e suas conexóes internas com uma população predominantemente muçulmana. O termo "golfo de Benin" corresponde aos estados do Daomé, Oyó e a área iorubá, estendendo-se até o Sudão Central. Finalmente, a designação baía de Biafra refere-se ao território ocupado pelos Igbos e Ibibios e a região de savana que chega até Camarôes. A principal distinção no interior da África Ocidental se dava entre as regióes muçulmanas do Sudáo ocidental, onde variaçóes do mandinga eram faladas, e partes do Sudão Central, onde o hausa era a língua franca. Essas classificaçóes reconhecem designaçôes regionais e internas relacionadas com a evolução política e histórica da África Ocidental e não com as "regiôes" artificiais criadas pelo banco de dados Slave voyages, que correspondem mais a uma perspectiva europeia vinculada ao comércio de escravos. O que eu proponho é o uso de termos regionais relevantes para a população africana.

O significado da origem das pessoas escravizadas é fator importante para o comércio de escravos, mas a análise até o momento não avalia os motivos pelos quais as regiôes muçulmanas eram marginais, apesar de sua relativa importância na Bahia, na América do Norte e seu impacto limitado na Jamaica, em Trinidade e em São Domingos. Na época de formação do Califado de Sokoto, a África Centro-Ocidental já era a principal fonte de escravos

\footnotetext{
${ }^{31}$ ELTIS, David; BEHRENDT, Stephen; RICHARDSON, David; FLORENTINO, Manolo. Voyages: The Transatlantic Slave Trade Database (Slave voyages). Disponível em: <www.slavevoyages.org/tast/database/search.faces >.
} 
para as Américas. A África Ocidental islâmica tinha participação restrita no mundo atlântico, apesar dos incentivos de preços no seu interior. Resistência de escravos nos portos da Senegâmbia durante o século XVIII pode ter influenciado a relutância dos capitães de navios negreiros europeus em visitar a área. ${ }^{32}$ Durante a "era das revoluçóes", as regiôes da África Centro-Ocidental e Oriental tornaram-se ainda mais importantes no comércio de escravos para as Américas. A África Ocidental, entretanto, perdeu importância devido às mudanças internas associadas à consolidação de governos de caráter islâmico que condenavam a venda de muçulmanos, o que acabou por efetivamente diminuir a participação da regiáo no mundo atlântico.

Quando comparada com as estimativas totais para a migração transatlântica de africanos no período 1808-1850, é evidente que a influência iorubá e muçulmana foi desproporcional em relação ao número de pessoas exportadas da regiâo chamada "golfo do Benim", isto é, a região que vai desde o rio Volta até o delta do rio Níger, incluindo aqui os Estados do interior, como Oyó e Alada, antes de 1727 e, posteriormente, Daomé como tributário de Oyó até 1823. O número de africanos deportados entre 1776 e 1867 demonstra a participaçáo relativamente baixa das regióes muçulmanas no comércio de escravos, tanto no período anterior como posterior à aboliçáo britânica em 1807. Aproximadamente 5,9 milhóes de pessoas deixaram a África no período (tabela 1), dos quais 2,7 milhóes foram deportados entre 1776 e 1807; após 1807, esse número aumentou para cerca de 3,2 milhôes, provavelmente associado ao sucesso do jihad que levou ao colapso dos estados hausas na primeira fase do movimento em Sokoto. Os eventos da abolição britânica e do jihad em Sokoto separaram os dois períodos, apesar de em ambos os momentos o número de africanos escravizados procedentes de áreas afetadas pelo movimento do jihad ter sido relativamente pequeno. Realmente, poucos muçulmanos foram enviados para as Américas e, portanto, é importante determinar em que regióes eles estavam concentrados.

\footnotetext{
${ }^{32}$ RICHARDSON, David. Shipboard revolts, African authority, and the Atlantic slave trade. William and Mary Quarterly, v. 58, n. 1, p. 69-92, 2001.
} 
Jihad na África Ocidental durante a "Era das Revoluçóes":

em direçấo a Um diálogo com ERIC Hobsbawm e Eugene Genovese

Paul E. Lovejoy

Tabela 1

Partidas da África para as Américas (1771-1850)

\begin{tabular}{|c|c|c|c|c|c|c|c|c|c|}
\hline Ano & $\begin{array}{c}\text { Sene- } \\
\text { gâmbia }\end{array}$ & $\begin{array}{c}\text { Serra } \\
\text { Leoa }\end{array}$ & $\begin{array}{c}\text { Costa a } \\
\text { Sotavento }\end{array}$ & $\begin{array}{c}\text { Costa } \\
\text { do Ouro }\end{array}$ & $\begin{array}{c}\text { Golfo } \\
\text { do } \\
\text { Benin }\end{array}$ & $\begin{array}{c}\text { Golfo } \\
\text { de } \\
\text { Biafra }\end{array}$ & $\begin{array}{c}\text { África } \\
\text { Centro- } \\
\text { Ocidental }\end{array}$ & $\begin{array}{c}\text { África } \\
\text { Oriental }\end{array}$ & Totais \\
\hline $\begin{array}{c}1776- \\
1800\end{array}$ & 84.920 & 94.694 & 73.938 & 285.643 & 261.137 & 336.008 & 822.056 & 822.056 & 2.008 .670 \\
\hline $\begin{array}{c}1801- \\
1825\end{array}$ & 91.225 & 89.326 & 37.322 & 80.895 & 201.054 & 264.834 & 929.999 & 929.999 & 1.876 .992 \\
\hline $\begin{array}{c}1826- \\
1850\end{array}$ & 17.717 & 84.416 & 6.131 & 5.219 & 209.742 & 230.328 & 989.908 & 989.908 & 1.770 .979 \\
\hline $\begin{array}{c}1851- \\
1867\end{array}$ & 0 & 4.795 & 0 & 0 & 33.867 & 2 & 156.779 & 156.779 & 225.609 \\
\hline Totais & 193.861 & 273.231 & 117.392 & 371.757 & 705.799 & 831.172 & 2.898 .741 & 2.898 .741 & 5.882 .250 \\
\hline
\end{tabular}

Fonte: ELTIS, David; BEHRENDT, Stephen; RICHARDSON, David; FLORENTINO, Manolo. Voyages: The Transatlantic Slave Trade Database (Slave voyages). Disponível em: <www.slavevoyages.org/tast/database/ search.faces>.

De acordo com David Eltis, 672 mil africanos identificáveis como iorubás deixaram o golfo do Benin entre 1776 e 1867. Na verdade, esta estimativa é provavelmente muito alta, uma vez que o número total de escravos saindo do golfo do Benim foi calculado em 706 mil, incluindo aqui os falantes de línguas gbes (como os fons, mahis, aladas, ewes etc.), que formaram a comunidade jeje na Bahia. Havia também muitas pessoas que se identificaram como hausas, nupes, bornos e baribas. Desses, Eltis identifica como iorubás 390 mil pessoas, (ou 55\% do total) que foram enviados para o Brasil, a maioria tendo como destino final a Bahia (371 mil) (tabela 2). Outros 99 mil (ou 14\% do total) foram para as ex-colônias espanholas - principalmente Cuba - e outros 42 mil (6\%) tiveram como destino Serra Leoa, como parte dos navios apreendidos pela marinha britânica. Aproximadamente 57 mil pessoas (8\%) foram enviadas ao Caribe britânico antes do fim do comércio de escravos em 1807, e 59 mil (8.3\%) para o Caribe francês, em particular a ilha de Sáo Domingos no período anterior à revolução na década de 1790 . Após essa data, a maioria dos iorubás foi enviada esmagadoramente para Cuba e a Bahia.

O número de pessoas exportadas oriundas da região iorubá e da área do jihad de Sokoto foi desproporcionalmente pequeno, apesar de sua importância no Brasil, especialmente na Bahia, assim como em Cuba e Serra Leoa. A maioria dos escravos africanos era proveniente da África Centro-Ocidental e de Moçambique, não da África Ocidental; grande parte foi transportada para o Brasil. Houve um cruzamento no movimento do comércio de escravos entre Cuba e Brasil que foi importante, de modo que os navios brasileiros e cubanos, muitas vezes sob a bandeira dos Estados Unidos e até mesmo de propriedade de norte-americanos, estavam envolvidos no comércio. ${ }^{33} \mathrm{O}$ percentual de iorubás e muçulmanos enviados às Amé-

\footnotetext{
${ }^{33}$ Ver: HORNE, Gerald. The deepest South: the United States, Brazil, and the African slave trade. Nova York: New York University Press, 2007.
} 
JiHAd Na ÁFrica Ocidental durante a "Era das Revoluçốes":

em direçấo A UM Dí́logo com ERIC HobsbaWm e Eugene Genovese

Paul E. Lovejoy

Tabela 2

Partidas de iorubás do golfo do Benin (1776-1867)

\begin{tabular}{|c|c|c|c|c|c|c|c|c|c|}
\hline Anos & $\begin{array}{c}\text { América } \\
\text { do Norte }\end{array}$ & $\begin{array}{c}\text { Caribe } \\
\text { Britânico }\end{array}$ & $\begin{array}{c}\text { Caribe } \\
\text { Francêss }\end{array}$ & $\begin{array}{c}\text { Caribe } \\
\text { Espanhol }\end{array}$ & Brasil & Bahia & $\begin{array}{c}\text { Sudeste } \\
\text { do } \\
\text { Brasil }\end{array}$ & África & Totais \\
\hline $\begin{array}{c}1776- \\
1800\end{array}$ & 0 & 33.000 & 57.100 & 2.900 & 79.300 & 79.300 & 0 & 0 & 172.900 \\
\hline $\begin{array}{c}1801- \\
1825\end{array}$ & 1.400 & 19.500 & 1.000 & 5.600 & 180.000 & 175.200 & 1.000 & 7.800 & 211.400 \\
\hline $\begin{array}{c}1826- \\
1850\end{array}$ & 0 & 4.700 & 1.200 & 65.600 & 128.300 & 116.200 & 28.400 & 32.400 & 257.400 \\
\hline $\begin{array}{c}1851- \\
1867\end{array}$ & 0 & 0 & 0 & 25.000 & 2.200 & 0 & 2.200 & 1.800 & 30.700 \\
\hline Totais & 1.400 & 57.200 & 59.300 & 99.100 & 389.800 & 370.700 & 31.600 & 42.000 & 672.400 \\
\hline
\end{tabular}

Fonte: ELTIS, David. The Yoruba diaspora in the Atlantic world: methodology and research. In: FALOLA, Toyin; CHILDS, Matt D. (Org.). The Yoruba diaspora in the Atlantic world, op. cit. p. 30-31.

Tabela 3

Partidas da África (1776-1867)

\begin{tabular}{|c|c|c|c|c|c|c|c|c|c|}
\hline Anos & $\begin{array}{c}\text { América } \\
\text { do Norte }\end{array}$ & $\begin{array}{c}\text { Carbe } \\
\text { Britânico }\end{array}$ & $\begin{array}{c}\text { Caribe } \\
\text { Francês }\end{array}$ & $\begin{array}{c}\text { Caribe } \\
\text { Holandês }\end{array}$ & $\begin{array}{c}\text { Caribe } \\
\text { Dinamar- } \\
\text { quês }\end{array}$ & Cuba & Brasil & África & Totais \\
\hline $\begin{array}{c}1776- \\
1800\end{array}$ & 36.277 & 661.330 & 455.797 & 59.294 & 43.501 & 64.373 & 670.655 & 1.967 & 2.008 .642 \\
\hline $\begin{array}{c}1801- \\
1825\end{array}$ & 93.000 & 206.310 & 73.261 & 28.654 & 19.597 & 254.869 & 1.130 .752 & 39.034 & 1.876 .992 \\
\hline $\begin{array}{c}1826- \\
1850\end{array}$ & 105 & 12.165 & 26.288 & 0 & 5.858 & 360.113 & 1.236 .577 & 111.771 & 1.770 .979 \\
\hline $\begin{array}{c}1851- \\
1867\end{array}$ & 475 & 0 & 0 & 0 & 0 & 195.989 & 8.812 & 20.332 & 225.609 \\
\hline Total & 129.858 & 879.805 & 555.346 & 87.948 & 68.956 & 875.344 & 3.046 .796 & 173.105 & 5.882 .222 \\
\hline
\end{tabular}

Fonte: ELTIS, David; BEHRENDT, Stephen; RICHARDSON, David; FLORENTINO, Manolo. Voyages: The Transatlantic Slave Trade Database (Slave voyages). Disponível em: <www.slavevoyages.org/tast/database/ search.faces>.

ricas foi relativamente pequeno quando comparado com outros grupos. Como pode ser visto na tabela 1 , pelo menos 2.493.000 escravos, ou seja, mais de 42,4\% de todos os africanos escravizados e deportados, eram oriundos da África Ocidental, incluindo aqui os embarcados na baía do Benin. Enquanto 831 mil, ou seja, 14,1\% dos escravos vieram do golfo de Biafra, de onde poucos iorubás e muçulmanos partiram. As pessoas capturadas nas áreas a oeste do delta do Níger que, possivelmente, foram afetadas pelo movimento do jihad não poderiam representar mais de 28,3\% do total do número de escravos exportados - e nós sabemos que uma proporção considerável desse total veio de áreas perto da costa que não foram afetadas pelo jihad. 
Jihad na África Ocidental durante a "Era das Revoluçóes":

em direçấo A UM Dí́logo com ERIC HobsbaWm e Eugene Genovese

Paul E. Lovejoy

Daí os africanos escravizados afetados pelo jihad terem sido provavelmente $10 \%$ ou menos em relação ao número total de africanos enviados para as Américas, que varia entre 550 mil e 600 mil. Estima-se que o número de escravos enviados através do deserto do Saara pode ter chegado a 700 mil indivíduos no século XVIII e 1,2 milhão no século XIX. Isso daria uma cifra de possivelmente um milhão de pessoas para o período entre 1776-1867. ${ }^{34}$ Não há como estimar o comércio interno de escravos na África Ocidental ou ainda a transferência de escravos como tributo, mas imagina-se que ambos tenham sido substanciais, repercutindo em migração interna. ${ }^{35}$ Esses números e a provável escala do tráfico interno sugerem a existência de escravos disponíveis para o mercado, embora poucos tenham sido enviados ao litoral atlântico. Ao que parece, muçulmanos escravizados foram enviados a lugares como Ibadan, Lagos e Ashante em vez de serem vendidos para o comércio atlântico.

As estimativas do tráfico de escravos devem ser comparadas com o tamanho das populaçóes escravizadas nos estados muçulmanos da África Ocidental, principalmente os Estados jihadistas de Fuuta Jallon, Fuuta Toro, Fuuta Bundu, o Califado de Sokoto, Hambullahi, 'Umarian Bamako e inúmeras cidades muçulmanas que estavam ao longo das rotas comerciais que ligavam essas entidades políticas a lugares como Ibadan, Lagos e Ashante. Não há estimativas exatas até o final do século XIX, com exceção daquelas deixadas pelos viajantes europeus que geralmente exageravam os números. Com as conquistas francesas, britânicas e alemãs, centenas de milhares de escravos fugiram, o que fez com que os governos coloniais tivessem de estimar o tamanho das populaçóes escravas em seus domínios para controlar o problema. ${ }^{36}$ Apesar da limitação das fontes primárias, é possível concluir que todos os estados que passaram por jihad e todos os centros urbanos na região da savana e do Sahel continham populaçóes escravas em número substancial, concentradas ao longo das principais rotas comerciais. ${ }^{37} \mathrm{Ou}$ seja, havia tantos escravos na África Ocidental que todos os

\footnotetext{
${ }^{34}$ Para estimativas do comércio de escravos saariano, ver: LOVEJOY, Paul E. Transformations in slavery: a history of slavery in Africa. 3. ed. Cambridge, 2011. p. 62, 142.

${ }^{35}$ Para o comércio interno de escravos africanos, ver ibid., p. 91-111, 139-164. Ver também LOFKRANTZ, Jennifer; LOVEJOY, Paul E. Crossing network boundaries: Islamic law and commerce from Sahara to Guinea shores. No prelo.

${ }^{36}$ Para uma discussão acerca da fuga de escravos no final do século XIX e primeiros anos do século XX, ver: KLEIN, Martin A. Slavery and colonial rule in French West Africa. Cambridge: Cambridge University Press, 1998; LOVEJOY, Paul E. Transformations in slavery, op. cit. p. 272-275; e LOVEJOY, Paul E.; HOGENDORN, Jan S. Slow death for slavery: the course of abolition in northern Nigeria, 1897-1936. Cambridge: Cambridge University Press, 1994. p. 31-63.

${ }^{37}$ Para uma discussão acerca do contingente da população escrava na África Ocidental islâmica, ver: LOVEJOY, Paul E. Transformations in slavery, op. cit. p. 191-220; LOVEJOY, Paul E. Slavery, commerce and production in West Africa: slave society in the Sokoto Caliphate. Trenton, NJ: Africa World Press, 2005; LOVEJOY, Paul E. The urban background of enslaved Muslims in the Americas. Slavery and Abolition, v. 26, n. 3, p. 347-372, 2005. Veja também, por exemplo, SALAU, Mohammed Bashir. The West African slave plantation: a case study. Nova York: Palgrave Macmillan, 2011; SALAU, Mohammed Bashir. Ribats and the development of plantations in the Sokoto Caliphate: a case study of Fanisau. Africa Economic History, v. 34, p. 23-43, 2006; SALAU, Mohammed Bashir. Slavery in Kano Emirate of Sokoto Caliphate as recounted:
} 
Jihad na África Ocidental durante a "Era das Revoluçóes":

cativos exportados para as Américas poderiam ter sido enviados dessa região. Porém isso não aconteceu. Visto que havia disponibilidade de escravos, a questão é saber por que eles foram utilizados localmente, não sendo vendidos aos comerciantes transatlânticos.

Estimativas da população para a África Ocidental no final do século XVIII e primeira metade do século XIX são naturalmente problemáticas. No entanto, o tamanho da população escrava no final do século XIX pode ser estimado a partir de relatos coloniais, especialmente em relação ao número de escravos que fugiram em direção ao território ocupado pelos franceses ou para o norte da Nigéria sob domínio britânico. O número de escravos na África Ocidental era expressivo. Para uma comparação, quando a Guerra Civil Americana irrompeu na década de 1860, havia cerca de 4 milhóes de escravos nos Estados Unidos. A população escrava dos Estados Unidos era tão grande quanto a que existia no Califado de Sokoto na década de 1850 . Vale lembrar que Sokoto era a região que estava no centro do movimento revolucionário que estou identificando como tendo sido ignorado, esquecido ou mal interpretado em grande parte da produção acadêmica sobre a "era de revoluçóes". 38

A consolidação do Islá, talvez ironicamente - considerando a importância da questão da escravidão aos olhos dos juristas na época - , favoreceu o aumento do número de africanos escravizados, muitos dos quais estavam concentrados na África Ocidental. Um número considerável foi enviado às Américas, principalmente para Bahia e Cuba, como demonstra o historiador João Reis na terceira edição ampliada de sua análise do levante dos malês de 1835. Como Reis observou, um jihad "fulani" abasteceu a Bahia de africanos escravizados adeptos do Islã. O autor destacou ainda que a Bahia recebeu grande número de escravos da Iorubalândia em consequência do colapso do império de Oyó. A influência desses africanos foi desproporcional ao seu número em várias regióes da diáspora. No Brasil, a presença muçulmana foi em maior número, seguido em importância numérica por Cuba, onde a maioria dos escravizados em jihad era de Oyó, mas não eram muçulmanos, e, por fim, por Serra Leoa, devido à imigração forçada dos africanos "emancipados" pela marinha britânica. Muitos deles trabalhavam em casas de ingleses ou para as empresas britânicas, sugerindo interseção entre os movimentos no interior da África Ocidental e a atuação da marinha britânica. Informaçóes devem ter sido trocadas no que diz respeito aos eventos em Serra Leoa, o fator iorubá e a revolta muçulmana. Essas ligaçóes indicam que a história da diáspora deve

testimonies of Isyaku and Idrisu. In: BELLAGAMBA, Alice; GREENE, Sandra E.; KLEIN, Martin A. (Ed.). African voices on slavery and the slave trade, vol. 1. Cambridge, Cambridge University Press, 2013. p. 88-116; SALAU, Mohammed Bashir. Slave trading in Kano Emirate. In: OJO, Olatunji; HUNT, Nadine (Ed.). Slavery in Africa and the Caribbean: a history of enslavement and identity since the eighteenth century. Londres: I. B. Tauris, 2012. p. 38-64; SALAU, Mohammed Bashir. Voices of those who testified on slavery in Kano Emirate. In: ARUAJO, Ana L.; CANDIDO, Mariana P.; LOVEJOY, Paul E. (Ed.). Crossing memories: slavery and African diaspora. Nova Jersey: African World Press, 2011. p. 129-145; e SALAU, Mohammed Bashir. Slaves in a Muslim city: a survey of slavery in nineteenth century Kano. In: LOVEJOY, Paul E. et al. (Ed.). Islam, slavery and the diaspora. Nova Jersey: African World Press, 2009. p. 91-101.

${ }^{38}$ Ver LOVEJOY, Paul E. Slavery, commerce and production in West Africa, op. cit. p. 9. 
JiHAd Na ÁFrica Ocidental durante a "Era das Revoluçốes":

em direçấo A UM Dí́logo com ERIC HobsbaWm e Eugene Genovese

Paul E. Lovejoy

incorporar eventos na África e evitar concentrar-se apenas nas Américas, principalmente no que diz respeito às formas de resistência e às manifestaçóes sociais, religiosas e culturais reconstituídas na diáspora.

O Islã era um fator que desencorajava a venda de escravos para as Américas. Ou seja, os muçulmanos no interior da África Ocidental influenciavam o mercado negreiro no litoral, em grande parte para evitar o comércio de escravos com os europeus. Líderes muçulmanos fizeram a opção de não participar no mercado atlântico. Assim, durante a "era das revoluçôes” na Europa e nas Américas, as revoluçôes de cunho religioso e militar na África Ocidental, os jihad, tiveram um impacto profundo na formação do mundo atlântico. Fatores religiosos e ideológicos impediam que os muçulmanos vendessem escravos para os europeus ou para comerciantes associados aos mercados transatlânticos. ${ }^{39}$ Houve exceçóes, exemplificadas pela presença de muçulmanos escravizados na Bahia, Jamaica e América do Norte, porém esses casos demonstram que, apesar dos esforços, os governantes muçulmanos da África Ocidental nem sempre eram bem-sucedidos em suas tentativas de boicote ao mercado transatlântico de africanos. Os esforços para evitar a participação da África Ocidental no tráfico de escravos no mundo atlântico coincidiram com a "era das revoluçôes" e o Islã era a motivação por trás desse boicote. ${ }^{40}$ Havia, eu defendo, uma tentativa consciente por parte dos governantes da África Ocidental para fazer valer a autonomia e evitar o envio de muçulmanos às Américas.

A produção literária de Ahmad Baba e seus colaboradores no final do século XVI e início do século XVII demonstra que os intelectuais e clérigos muçulmanos da África Ocidental estavam conscientes da existência da escravidão transatlântica e elaboraram uma resposta ao que, para alguns, parecia ser um meio atraente de obter lucros. ${ }^{41}$ As restriçóes impostas por esses líderes limitou o envolvimento de muçulmanos no comércio com os europeus, isto é, cristãos. Embora a participação não tenha sido totalmente eliminada, poucos foram os muçulmanos enviados às Américas em comparação ao número total de africanos deportados. Proporcionalmente, os números eram reduzidos e houve forte resistência a um envolvimento mais sério, o que foi efetivamente cumprido.

\footnotetext{
${ }^{39}$ LOFKRANTZ, Jennifer; LOVEJOY, Paul E. Maintaining network boundaries, op. cit.

${ }^{40}$ LOVEJOY, Paul E. Islam, slavery, and political transformation in West Africa: constraints on the trans-Atlantic slave trade. Outre-Mers: Revue d'Histoire, v. 89, p. 247-282, 2002. Ver também LOVEJOY, Paul E. (Ed.). Slavery on the frontiers of Islam, op. cit.; e MIRZAI, Behnaz; MONTANA, Ismael M.; LOVEJOY, Paul E. (Ed.). Islam, slavery and diaspora, op. cit. Uma exceção é o trabalho de SILVA, Alberto da Costa e. Sobre a rebelião de 1835 na Bahia. Revista Brasileira, v. 31, p. 9-33, 2002, e reimpresso em SILVA, Alberto da Costa e. Um rio chamado Atlântico: a África no Brasil e o Brasil na África. Rio de Janeiro: Nova Fronteira, 2003. p. 189-214. Ver ainda LOVEJOY, Henry B. Old Oyo influences on the transformation of Lucumí identity in colonial Cuba, op. cit.

${ }^{41}$ LOVEJOY, Paul E. The context of enslavement in West Africa: Ahmad Bābā and the ethics of slavery. In: LANDERS, Jane (Ed.). Slaves, subjects, and subversives: Blacks in colonial Latin America. Albuquerque: University of New Mexico Press, 2006. p. 9-38; e HUNWICK, John; HARRAK, Fatima. Mi'raj al-su'ud: Ahmad Baba's replies on slavery. Rabat: Institut des Etudes Africanes; Université Mohamed V, 2000.
} 
JiHAd Na ÁFrica Ocidental durante a "Era das Revoluçốes":

A escravidáo era um fator de debate no movimento do jihad, particularmente as queixas de que muçulmanos nascidos livres estavam sendo escravizados, apesar de ser ilegal sob a lei islâmica e uma violação de seus direitos. A medida tinha a intenção de proteger os muçulmanos e não deve ser entendida como uma oposição à instituição da escravidão, que continuava a ser central para a manutenção da sociedade e da economia do Califado de Sokoto ao longo da primeira metade do século XIX. Por isso, o movimento revolucionário do jihad que varreu a África Ocidental no período da "era das revoluçôes", teve um impacto muito diferente sobre o curso da escravidão, mas ainda assim as dimensões revolucionárias do jihad foram profundas e exigem análise como um movimento paralelo às forças que Hobsbawm e Genovese estavam interessados. As preocupaçôes com os direitos dos muçulmanos nascidos livres e a insistência no estado de direito foram dirigidas a governos aleatórios. É importante ressaltar que uma das decisóes a ser tomada, nesses casos, dizia respeito à legalidade da escravização. A venda de muçulmanos nascidos livres para os cristãos atuantes no comércio transatlântico de escravos era inevitavelmente ilegal. O movimento do jihad, nesse sentido, deve ser interpretado como uma reação aos excessos do ancien régime na Europa, ainda que de forma indireta.

O movimento do jihad favoreceu a autonomia da África Ocidental ao mesmo tempo que a escravidáo na regiáo se expandiu de forma expressiva, principalmente na regiáo do Sudão Central estendendo-se para Oyó, de onde vieram muitos dos escravizados que foram transportados para Cuba e Brasil. A interconectividade e as contradiçóes que surgiram exigem tratamento mais completo do que tem sido dedicado à resistência escrava durante a "era das revoluçôes". Uma das grandes transformaçóes do período, o debate sobre a legitimidade da escravização, tem recebido pouca atenção por parte de historiadores. Esse debate se revela na troca de correspondência entre Muhammad Bello e Muhammad al-Kanemi, respectivamente, os chefes de estado do Califado de Sokoto e Borno, assim como a guerra entre esses estados em consequência da impossibilidade de chegar a um acordo aceitável sobre a implementaçáo da reforma religiosa e o curso do jihad .2 $^{42} \mathrm{Ou}$ ainda as negociaçóes diplomáticas entre Grã-Bretanha e Sokoto sobre o comércio de escravos. O califa Muhammad Bello, governante supremo do Califado de Sokoto, e o capitão Hugh Clapperton, representante oficial do governo britânico, formalmente concordaram com a abolição do tráfico de

${ }^{42}$ Sobre Borno, consultar: ALKALI, Muhammad N. El-Kanemi's response to the extension of Shaykh 'Uthman Dan Fodio's Jihad against Borno. In: BOBBOYI, H.; YAKUBU, A. M. (Ed.). The Sokoto Caliphate, op. cit. v. 1, p. 231-239; BRENNER, Louis. The Jihad debate between Sokoto and Borno, op. cit. p. 21-43; e BRENNER, Louis. The Shehus of Kukawa, op. cit. Ao menos vinte cartas foram trocadas entre a liderança do jihad e al-Kanemi entre 1808-1812. Muitas das cartas estão em BELLO, Muhammad. Infäq al-Maysūr fī tārìkh biläd at-Takrūr, op. cit.; outra carta de el-Kanemi para Goni Mukhtar, o líder das forças do jihad em Borno, datada de 17 Rabi' al-Awwil 1223 (13 de maio de 1808), está disponível na Biblioteca da Universidade de Ibadan (Mss 82/237). Ver LAST, D. M.; AL-HAJJ, M. A. Attempts at defining a Muslim in $19^{\text {th }}$ century Hausaland and Bornu. Journal of the Historical Society of Nigeria, v. 3, n. 2, p. 239, 1965; e BRENNER, Louis. The Shehus of Kukawa, op. cit. p. 39-43. 
JiHAd Na ÁFrica Ocidental durante a "Era das Revoluçốes":

em direção a um diálogo com ERIC HobsbaWm e Eugene Genovese

Paul E. Lovejoy

escravos em 1824, o que traz para o foco as contradiçóes da "era das revoluçóes". ${ }^{43}$ Esses são temas que merecem mais atenção por parte dos historiadores porque afetam diretamente a organização do comércio de escravos.

Além disso, assim como eventos nas Américas revelam uma disputa entre a resistência à escravidão e os esforços para sustentar o que alguns pensavam ser uma instituição moribunda, os acontecimentos na África revelam a expansão da escravidão e não a sua morte. $\mathrm{O}$ foco na mudança revolucionária em relação à resistência à escravidão precisa levar em conta o destino da população escrava, seja daqueles que permaneceram na África ou dos que foram enviados para as Américas. A experiência do Oeste africano levanta outro debate importante. O sociólogo e historiador Dale Tomich cunhou o conceito de "segunda escravidão" para descrever o aumento da escravidão no início do século XIX, graças a uma nova ordem política imposta pelos britânicos após a queda de Napoleão. ${ }^{44}$ Essa situação era paralela à grande expansão da escravidão com o jihad na África Ocidental.

É preciso entender o grau de influência do movimento do jihad, sua extensão e o modo pelo qual tal expansão ocorreu. Por que o movimento do jihad não foi ainda mais influente em seu impacto nas Américas, já que era tão extenso na África Ocidental? A análise demográfica sugere uma relativa insignificância no número de muçulmanos escravizados a partir de meados do século XVIII até o fim do comércio na década de 1850, o que suscita questôes adicionais. Como alguns muçulmanos foram escravizados? De onde exatamente eles vieram? Quando e como foram capturados? Essas questóes são importantes para a melhor compreensão da demografia da escravidão na África Ocidental bem como para um melhor entendimento da escala da escravidão e da relação estabelecida entre os estados muçulmanos fundados no contexto de jihad com outros centros urbanos e regióes.

Ignorar o movimento do jihad afeta a compreensão da escravidão nas Américas durante o século XIX. Em primeiro lugar, as regiōes muçulmanas da África Ocidental mantiveram uma autonomia de relativo sucesso com relação ao tráfico transatlântico de escravos, com

\footnotetext{
43 Minha discussão acerca das negociações entre Bello e Clapperton foi inicialmente apresentada em "Rethinking the African diaspora: the making of a Black Atlantic World in the bight of Benin and Brazil", Emory University, de 17 a 18 de abril de 1998, e foi posteriormente publicada como: The Clapperton-Bello exchange: the Sokoto Jihad and the trans-Atlantic slave trade, 1804-1837. In: WISE, Christopher (Ed.). The desert shore: literatures of the African Sahel. Boulder: Lynne Rienner, 2000. p. 201-228. Os argumentos apresentados foram expandidos em: Diplomacy of abolition: negotiations between Muhammad Bello and Hugh Clapperton over the abolition of the Atlantic slave trade. In: COTTIAS, Myriam; ROSSIGNOL, Marie-Jeanne (Ed.). Distant ripples of the British abolitionist wave in Africa, the Americas and Asia. Trenton, NJ: Africa World Press, no prelo.

${ }^{44}$ TOMICH, Dale. Through the prism of slavery: labor, capital and world economy. Lantham: Bowman \& Littlefield, 2004; KAYE, Anthony E. The second slavery: modernity in the nineteenth-century South and the Atlantic world. Journal of Southern History, v. 75, n. 3, p. 627, 2009. Ver também ELTIS, David; RICHARDSON, David. Atlas of the transatlantic slave trade. New Haven; Londres: Yale University Press, 2010. p. 189, map. 131, para informaçóes acerca das revoltas em navios negreiros e porcentagem por regióes africanas dos escravos que embarcaram entre 1566-1865.
} 
poucas exceções. Antes da abolição britânica em 1807, praticamente todos os escravos que vieram de áreas muçulmanas da África Ocidental foram para as Américas a partir do interior do Sudão Ocidental, em particular capturados na região da Senegâmbia e da costa da Guiné superior até a península de Cabo Monte, no norte da Libéria. Após a abolição britânica, os escravos das áreas muçulmanas vieram em grande parte do interior do golfo de Benin e do Sudão Central, apesar de alguns continuarem a vir do oeste do Sudão, seguindo as rotas comerciais que operavam desde o século XVIII e, possivelmente, períodos anteriores. Em segundo lugar, a autonomia das regiōes muçulmanas é particularmente notável quando se considera a importância relativa de escravos de áreas muçulmanas nas Américas em comparação com as origens dos escravos de regióes não muçulmanas. Para a migração transatlântica como um todo, menos de $10 \%$ da população escravizada veio de áreas onde os muçulmanos eram política ou economicamente dominantes. Por outro lado, cerca de metade de todos os escravos veio de regiōes de língua bantu, onde o Islã não era conhecido e onde não havia muçulmanos. Muitos outros africanos que foram enviados às Américas eram oriundos do interior da baía de Biafra, onde não havia influência islâmica, ou ainda de áreas ao longo da costa oriental africana onde o Islã era mais evidente em aspectos comerciais. Os escravos do litoral oriental da África foram capturados como consequência das tensões políticas e sociais entre os estados e sociedades costeiras e os territórios no interior.

\section{A influência do jihad nas Américas}

O problema que se coloca é como inserir a "era do jihad" na "era das revoluçóes". A limitação maior é associar rebeliôes escravas com etnicidades específicas quando, em alguns casos, a religião foi o fator dominante de organização e motivação. Aqueles que foram escravizados e enviados para o Brasil e Cuba foram muitas vezes referidos como nagô, lucumí ou aku, que correspondem a grupos de iorubás, ou ainda nomes semelhantes como hausa, nupe ou outros rótulos que muitas vezes só se referem à lingua falada, que não deve ser confundida com etnia ou lealdade ao Islã. O que é etnia? Como o uso da língua como um elemento de identificação afeta a análise histórica? Como eram as designaçóes étnicas empregadas na África Ocidental e, particularlmente, na região de onde vieram as pessoas afetadas pelos jihad? Em textos anteriores, fiz uma tentativa de abordar essas questóes utilizando o que chamei de "metodologia através da lente étnica", que prioriza a identificação de etnias e línguas em contextos históricos específicos. Nela, os termos étnicos devem ser analisados criticamente para evitar confusóes com outras identificações associadas aos campos políticos, religiosos, laborais, territoriais e de gênero. ${ }^{45}$ Refiro-me especificamente às minhas

\footnotetext{
${ }^{45}$ LOVEJOY, Paul E. Methodology through the ethnic lens. In: FALOLA, Toyin; JENNINGS, Christian (Ed.). Sources and methods in African history: spoken, written, unearthed. Rochester: University of Rochester Press, 2003. p. 105-117.
} 
JiHAd Na ÁFrica Ocidental durante a "Era das Revoluçốes":

em direçấo A UM Dí́logo com ERIC HobsbaWm e Eugene Genovese

Paul E. Lovejoy

publicaçóes sobre o comércio de noz-de-cola, a produção de sal, o intercâmbio comercial, escravidão e jihad. ${ }^{46}$

Ilorin foi particularmente importante por causa do papel que desempenhou na migração de iorubás para Cuba e o Brasil e ainda para Serra Leoa, Trinidade e outros países, indiretamente. Pessoas que se identificavam com Oyó estavam predominantemente em Cuba e na Bahia, com muitos escravos de origem Oyó associados com Xangô, os tambores batá e a transformação do Dia de Reis no festival bere (associado ao principal festival de Xangô em Oyó). ${ }^{47}$ Os muçulmanos escravizados que serviam no exército de Ilorin e que se rebelaram em 1817 costumam ser identificados como hausa, e o termo nagô é utilizado para os indivíduos vinculados à rebelião malê. Ao fazer uso da metodologia que usa a etnia como uma lente de aumento, nos perguntamos o significado dessas designaçóes étnicas. Em ambos os casos, há um importante componente linguístico, porém o conhecimento de uma língua não necessariamente determina a origem étnica. Em Ilorin, ser hausa significava, independentemente das origens diversas, ser falante da língua hausa e ser muçulmano, de nascimento ou convertido - no caso daqueles que eram de Kano, Katsina ou ainda das terras distantes de Adamawa. Na Bahia, ser iorubá significava utilizar o iorubá como língua comum, embora muitos também falassem o hausa, nupe ou outras línguas. Qualquer tentativa de simplificar as transformações na identificação como um rótulo étnico essencialista — o "hausa" ou o "iorubá” — está fadada a criar confusão e essencializar as identidades africanas. É preciso considerar a complexidade e as imprecisões das designaçóes étnicas para tentar determinar quem eram os iorubás e os hausas no momento do levante em Ilorin de 1817 ou na Bahia na época da revolta dos malês de 1835. Como o historiador Olatunji Ojo observou, a religião também desempenhou um papel unificador, incorporando socialmente os que vinham de regiôes além do Sudão Central. Na verdade, não demorou muito para os membros das brigadas de origem iorubá serem identificados como "hausa", o que criava uma série de oportunidades. Em iorubá, esses mesmos indivíduos eram chamados de "gambari" e, de fato, nem mesmo eram de origem hausa. ${ }^{48}$

\footnotetext{
${ }^{46}$ LOVEJOY, Paul E. Ecology and ethnography of Muslim trade in West Africa. Trenton, NJ: Africa World Press, 2005; LOVEJOY, Paul E. Salt of the desert sun. A history of salt production and trade in the Central Sudan. Cambridge: Cambridge University Press, 1986; LOVEJOY, Paul E. Caravans of Kola. The Hausa Kola trade, 1700-1900. Zaria: Ahmadu Bello University Press, 1980; e LOVEJOY, Paul E. Slavery, commerce and production in West Africa, op. cit.

${ }^{47}$ LOVEJOY, Henry B. Old Oyo influences on the transformation of Lucumí identity in colonial Cuba, op. cit.; LOVEJOY, Henry B. Drums of Șàngó, op. cit. p. 284-308; LOVEJOY, Henry B. Transculturation of Yoruba annual festivals, op. cit. p. 33-50.

${ }^{48}$ OJO, Olatunji. Islam, ethnicity and slave agitation: Hausa 'Mamluks' in nineteenth century Yorubaland. In: MIRZAI, Behnaz A.; MONTANA, Ismael Musah; LOVEJOY, Paul E. (Ed.). Slavery, Islam and diaspora, op. cit. p. 103-124. Em 1899, o prefeito Francis C. Fuller — segundo oficial britânico residente em Ibadan — descreveu "gambari" como "pertencendo a qualquer tribo para além do [rio] Níger", mas que falava hausa independentemente de quaisquer outras línguas que eles soubessem. Ver FULLER, journal, 21 January 1899, IbaProf 3/6, Nigerian Archives, Ibadan. Agradeço a Olatunji Ojo por essa referência.
} 
Samuel Ajayi Crowther, de origem Oyó, atribuiu a destruição de muitas cidades de Oyó na década de 1820 a muçulmanos de Oyó, a quem ele chamou de fulanis, embora muitos falassem iorubá. ${ }^{49}$ Da mesma forma, os diplomatas britânicos Hugh Clapperton e John Lander relataram a destruição de inúmeras cidades na década de 1820, associada às açôes dos muçulmanos, a quem chamavam de fulanis. Esses relatos são baseados em suas observaçôes pessoais durante a viagem de Badagri para Katunga, a capital de Oyó, em 1826-1827 e novamente por Lander em 1830. É difícil questionar os relatos de Clapperton e Lander, com vasta experiência de viagens na África Ocidental. Os autores observaram ainda o fato de que várias pessoas falavam mais de uma língua, bem como o papel do Islã como uma força revolucionária em Oyó. Samuel Crowther chegou a conhecer vários soldados "iorubás" em 1841 e em 1857, quando estavam a serviço dos emirados Nupe. Esses soldados falavam fluentemente o iorubá, assim como o hausa, o nupe e o fula, uma vez que viviam nos emirados muçulmanos onde estavam empregados, sendo identificados como fulanis, em si um termo hausa utilizado para designar os falantes de fulfulde.$^{50}$ Clapperton e Lander descreveram um caminho de destruição que ia do centro de Oyó e da capital Katunga até a costa e particularmente envolvendo Owu. ${ }^{51}$ Outras fontes contemporâneas confirmam que a identificação étnica era complexa e a religiáo funcionava como um fator decisivo. Faz-se necessário o emprego de uma metodologia de análise de identificadores étnicos que relacione identidade com as línguas que as pessoas eram capazes de falar e sua filiação religiosa. Para mim, o reconhecimento de uma designação étnica é a primeira etapa no processo de entendimento da história e não uma explicação em si mesma. É por isso que defendo a utilização de uma "metodologia através da lente étnica".

Assim, no período de revoluçóes na Europa e no mundo atlântico, houve um movimento de contrabalanço no interior da África Ocidental que isolou a regiâo da "era das revoluçóes". Esse movimento teve diferentes consequências na história da escravidão e, portanto, em nosso entendimento da história desse período. Em meados do século XIX, havia mais escravos em áreas muçulmanas da África Ocidental do que nas Américas durante todo o período do comércio transatlântico. Apesar disso, a historiografia sobre a era das revoluções omite qualquer informação sobre os jihad e a preponderância da escravidão na África Ocidental,

\footnotetext{
${ }^{49}$ Crowther to Jowett, 22 February 1837 [1942]. In: SCHÖN, Frederick; CROWTHER, Samuel. Journals of the Rev. Frederick Schön and Mr. Samuel Crowther: expedition up the Niger in 1841. Londres: Frank Cass, 1970. appendix III; e CROWTHER, Samuel; TAYLOR, John C. The Gospel on the banks of the Niger: journals and notices of the native missionaries accompanying the Niger expedition of 1857-1859 [1859]. Londres: Frank Cass, 1968. p. 100, 126-127.

${ }^{50}$ Crowther to Jowett, 22 February 1837. In: SCHÖN, Frederick; CROWTHER, Samuel. Journals of the Rev. Frederick Schön and Mr. Samuel Crowther, op. cit. appendix III; e CROWTHER, Samuel; TAYLOR, John C. The Gospel on the banks of the Niger, op. cit. p. 100, 126-127.

${ }^{51}$ LOCKHART, Jamie Bruce; LOVEJOY, Paul E. (Ed.). Hugh Clapperton into the interior of Africa, op. cit. p. 36-37, 40-50, 55, 57; LANDER, Richard. Records of captain Clapperton's last expedition to Africa. Londres: Colburn and Bentley, 1830. 2 v.; LANDER, Richard; LANDER, John. Journal of a narrative to explore the course and termination of the Niger. Nova York: J. \& J. Harper, 1832. 2 v.
} 
JiHAd Na ÁFrica Ocidental durante a "Era das Revoluçốes":

em direçấo A UM Dí́logo com ERIC HobsbaWm e Eugene GENovese

Paul E. Lovejoy

excluindo aqui os estados costeiros de Ashante, Daomé ou ainda o interior Igbo da baía de Biafra, onde a escravidão também foi amplamente disseminada sem nunca atingir os números encontrados nos califados. Embora a África Ocidental não tenha exportado grandes números de muçulmanos para o Atlântico Negro, uma quantidade expressiva de indivíduos permaneceu em cativeiro localmente. As razóes para essa abstenção de envolvimento no comércio transatlântico de escravos eram de natureza política e religiosa e foram o resultado das decisões de lideranças políticas e comerciais. Quando encontramos muçulmanos concentrados nas Américas, o seu papel na resistência à escravidão muitas vezes é minimizado. ${ }^{52}$ Reis, por exemplo, destaca o papel dos muçulmanos na insurreição malê: "Não nego a hegemonia dos malês no bloco rebelde, nego sua solidão. [...] Como eles detinham a hegemonia política do movimento de 1835 , podemos dizer que a rebeliāo foi malê e o levante foi africano".53

Em outras palavras, para Reis o movimento foi multifacetado, concebido principalmente por pessoas escravizadas interessadas em lutar por sua liberdade e reunindo indivíduos de diferentes credos (Islá, Orixá, Vodum etc.). Enquanto Reis reconhece a presença de fatores islâmicos e étnicos, para ele o Islã não era a principal motivação na rebelião de 1835 . É importante analisar as interaçôes no mundo atlântico e como as pessoas mantiveram ligaçóes religiosas e históricas com o Sudão Central no período do jihad. A questão não é se a jihad foi ou não um fator de identidade, mas como a jihad e a relação com Oyó influenciaram a identidade, a cosmologia e a resistência. ${ }^{54}$

\footnotetext{
${ }^{52}$ Alguns estudiosos, notavelmente Michael Gomez, Sylviane Diouf e outros, têm se dedicado à compreensão da presença anômala dos muçulmanos escravizados nas Américas e têm tratado da revolta dos malês na Bahia bem como do impacto do Islã. Inquestionavelmente, João Reis apresentou a análise mais detalhada da revolta dos malês no contexto da influência muçulmana mas, como Alberto da Costa e Silva demonstrou, Reis posteriormente abandonou em grande parte sua apreciação inicial do fator islâmico. Costa e Silva explorou a literatura acadêmica acerca do fator islâmico no interior da baía do Benin. Ver SILVA, Alberto da Costa e. Sobre a rebelião de 1835 na Bahia, op. cit. p. 189-214.

${ }^{53}$ REIS, João José. Rebelião escrava no Brasil: a história do levante dos malês em 1835. São Paulo: Companhia das Letras, 2003. p. 271. Reis faz referência aos documentos árabes escritos pelos malês, mas sua discussão acerca da literatura acadêmica sobre o jih ad é limitada. Enquanto ele faz referência à "Background to rebellion" de Lovejoy e "Sobre a rebelião de 1835 na Bahia" de Costa e Silva, sua discussão das fontes e das implicaçóes da tradição literária do Califado de Sokoto bem como de suas redes comerciais apresenta limitaçóes.

${ }^{54}$ Minha crítica é feita no contexto de uma produção acadêmica extensiva. Ver, por exemplo, REIS, João José. Slave Rebellion in Brazil e a versão revisada e expandida Rebelião escrava no Brasil, op. cit. p. 271. Também ver REIS, João José. Slave resistance in Brazil: Bahia, 1807-1835. Luso-Brazilian Review, v. 25, n. 1, p. 111144, 1988; e REIS, João José; FARIAS, Paulo F. de Moraes. Islam and slave resistance in Bahia, Brazil. Islam and Sociétés au Sud du Sahara, v. 3, p. 41-66, 1989; MOURA, Clóvis. Rebelióes da senzala. São Paulo, 1959; LUNA, Luis. O negro na luta contra a escravidão. Rio de Janeiro, 1967; KENT, Raymond. African revolt in Bahia. Journal of Social History, v. 3, p. 334-356, 1970; PRINCE, Howard. Slave rebellion in Brazil, 18071835. Tese (Ph.D.) Columbia University, Nova York, 1972; MATTOSO, Kátia M. de Queirós. Os escravos na Bahia no alvorecer do século XIX: estudo de um grupo social. Revista de História, Sáo Paulo, v. 47, n. 97, p. 109-135, 1974; e VERGER, Pierre. Trade relations between the Bight of Benin and Bahia, op. cit. Ver também QUIRING-ZOCHE, Rosemarie. Glaubenskampf oder Machtkampf? Der Aufstand der Malé von Bahia nach einer islamischen Quelle. Sudanic Africa, v. 6, p. 115-124, 1995. Muitos dos registros judiciais foram
} 
JiHAd Na ÁFrica Ocidental durante a "Era das Revoluçốes":

em direçấo A UM Dí́logo com ERIC HobsbaWm e Eugene GENOVESe

Paul E. Lovejoy

A tradição intelectual muçulmana precisa ser enfatizada, pois intelectuais contemporâneos ao movimento do jihad deixaram suas contribuiçóes. A correspondência entre Muhammad Bello e Muhammad al- Kanemi revela um debate intenso sobre a definição de quem era ou não muçulmano, documentação que não deveria ser menosprezada pelos especialistas em resistência escrava nas Américas. Do mesmo modo, as negociaçóes entre Muhammad Bello e Hugh Clapperton sobre a abolição do tráfico de escravos devem ser estudadas. ${ }^{55}$ Dados biográficos indicam como os jihad influenciaram a presença muçulmana, tanto na Bahia como em outros lugares. ${ }^{56}$ Essa extensa produção intelectual é útil para a análise do papel dos muçulmanos nas Américas. ${ }^{57}$ Priscilla Mello, José Cairus e Alberto da Costa e Silva ana-

publicados. Ver: Devassa do levante de escravos ocorrido em Salvador em 1835. Anais do Arquivo do Estado da Bahia, Salvador, v. 38, 1968; Peças processuais do levante dos malês. Anais do Arquivo Público do Estado da Bahia, Salvador, v. 40, 1971; Devassa do levante de escravos ocorrido em Salvador em 1835. Anais do Arquivo Público do Estado da Bahia, Salvador, v. 50, 1992; Devassa do levante de escravos ocorrido em Salvador em 1835. Anais do Arquivo do Estado da Bahia, v. 53, Salvador, 1996. Um volume final foi publicado em 1997.

${ }^{55}$ LOVEJOY, Paul E. Diplomacy of abolition, op. cit. Para informaçóes acerca do contexto político do debate Sokoto-Borno, Ver: BRENNER, Louis. The Jihad debate between Sokoto and Borno, op. cit. p. 21-43.

${ }^{56}$ Apesar dos esforços para documentar o jihad e seu impacto em Oyó bem como a posterior diáspora iorubá nas Américas e na África Ocidental, as fontes disponíveis são geralmente negligenciadas. Por exemplo, a segunda expedição do diplomata britânico Hugh Clapperton, uma das poucas fontes primárias sobre o período 1817-1827, oferece um relato do declínio de Oyó como resultado do jihad. No entanto, a versão cuidadosamente editada desse relato é praticamente ignorada (LOCKHART, Jamie Bruce; LOVEJOY, Paul E. (Ed.). Hugh Clapperton into the interior of Africa, op. cit.). De modo semelhante, a produção sobre a escravidáo no Califado de Sokoto tem sido ignorada. Porém, o Califado teve grande influência no comércio de escravos como fonte potencial de muito mais escravos do que aqueles que acabaram indo para as Américas no período. Transformations in slavery coloca o movimento do jihad no contexto da história africana dos séculos XVIII e XIX. A análise detalhada das fontes primárias que serviram de base para esses vários estudos é somente notada aqui. A riqueza da documentação oferece o contexto para o diálogo com Hobsbawm e Genovese e, implicitamente, com a produção dos estudos atlânticos e da história do Atlântico Negro. Ver: LOVEJOY, Paul E. Jihad e escravidão: as origens dos escravos muçulmanos da Bahia. Topoi, Rio de Janeiro, v. 1, p. 11-44, jan./dez. 2000, que é a revisão de LOVEJOY, Paul E. Background to rebellion: the origins of Muslim slaves in Bahia. Slavery and Abolition, v. 15, n. 2, p. 151-180, 1994. Ver também LOVEJOY, Paul E. Jihad and slavery: the origins of enslaved Muslims in Bahia. In: LOVEJOY, Paul E. Slavery, commerce and production in West Africa, op. cit. p. 55-80; e LOVEJOY, Paul E. Slavery on the frontiers of Islam, op. cit. ${ }^{57}$ REIS, João José. Ethnic politics among Africans in nineteenth-century Bahia. In: LOVEJOY, Paul E. (Ed.). Identity in the shadow of slavery. Londres: Continuum, 2000. p. 240-264; REIS, João José. African Nations and cultural practices in nineteenth-century Salvador, Bahia. Conferência no "American Counterpoint: New Approaches to Slavery and Abolition in Brazil”, Yale University, 2010; REIS, João José. Resistência escrava na Bahia. "Poderemos brincar, folgar e cantar...": o protesto escravo na América. Afro-Ásia, v. 14, 1983; REIS, João José. Um balanço dos estudos sobre as revoltas escravas da Bahia. In: REIS, João José (ed.). Escravidão e invenção da liberdade. Brasiliense: São Paulo, 1988; REIS, João José; SILVA, Eduardo. Negociação e conflito: resistência negra no Brasil escravista. São Paulo: Companhia das Letras, 1989. Ver ainda FARIAS, P. F. de Moraes. "Yoruba origins" revisited by Muslims. In: FARIAS, P. F. de Moraes; BARBER, Karin (Ed.). Selfassertion and brokerage: early cultural nationalism in West Africa. Birmingham: Centre of West African Studies, 1990. p. 109-147; FARIAS, P. F. de Moraes. Enquanto isso, do outro lado do mar: os Arókin e a identidade iorubá. Afro-Ásia, v. 17, p. 139-155, 1996; e BARICKMAN, B. J. Reading the 1835 Parish censuses from Bahia: citizenship, kinship, slavery, and household in early nineteenth-century Brazil. The Americas, v. 59, n. 3, p. 287-324, 2003. 
JiHAd Na ÁFrica Ocidental durante a "Era das Revoluçốes":

em direçấo A UM Dí́logo com ERIC HobsbaWm e Eugene GENovese

Paul E. Lovejoy

lisaram a origem africana dos participantes do levante dos malês. ${ }^{58} \mathrm{~A}$ influência muçulmana requer a utilização de uma bibliografia extensa de fontes primárias sobre a história iorubá e o movimento do jihad associado a Sokoto e Gwandu e à liderança de Uthman Dan Fodio, Abdullahi Dan Fodio e Muhammad Bello. Esses fatores têm apontado para uma estreita ligação entre a migração iorubá, o jihad e a presença muçulmana nas Américas. ${ }^{59}$

\section{Indivíduos no comércio de escravos}

A análise dos indivíduos escravizados durante a era do jihad enfatiza questóes metodológicas e de identidade, o que inevitavelmente provoca um reexame do significado da etnicidade nas regiōes muçulmanas da África Ocidental e na diáspora, inclusive na Bahia. Felizmente existem várias fontes primárias que lançam luz sobre essas questóes, como o livro History of the Yorubas, de Samuel Johnson. ${ }^{60}$ Outros textos, como os escritos por Uthman Dan Fodio, Abdullahi Dan Fodio, Muhammad Bello, Nana Asma'u, Waziri Junaidu al-Bukhari, Muhammad al-Kanemi, al-Hajj 'Umar também fornecem informaçóes sobre as designações étnicas na África Ocidental. ${ }^{61}$ Existem relatos de europeus que viajaram pelo

\footnotetext{
${ }^{58}$ MELLO, Priscilla. Leitura, encantamento e rebeliáo: o Islã Negro no Brasil, século XIX. Tese (doutorado) - Universidade Federal Fluminense, Niterói, 2009; CAIRUS, José. Jihad, captivity and redemption: slavery and resistance in the Path of Allah, Central Sudan and Bahia. Paper não publicado apresentado na conferência "Slavery and Religion in the Modern World", Essaouira (Morrocos), 2001; CAIRUS, José. Instrumentum vocale, mallams e alufás: o paradoxo islâmico da erudição na diáspora africana no Atlântico. Topoi, Rio de Janeiro, v. 4, n. 6, p. 128-164, jan./jun. 2003; e CAIRUS, José. Jihad, cativeiro e redenção: escravidão, resistência e irmandade, Sudão Central e Bahia (1835). Dissertação (mestrado) — Programa de Pós-graduação em História, Universidade Federal do Rio de Janeiro, Rio de Janeiro, 2002.

${ }^{59}$ LOVEJOY, Paul E. The Central Sudan and the Atlantic slave trade. In: HARMS, Robert W.; MILLER, Joseph C.; NEWBURY, David C.; WAGNER, Michelle D. (Ed.). Paths to the past: African historical essays in honor of Jan Vansina. Atlanta: African Studies Association, 1994. p. 345-370; e LOVEJOY, Paul E. The Yoruba factor in the trans-Atlantic slave trade, op. cit. p. 40-55.

${ }^{60}$ JOHNSON, Samuel. The history of the Yoruba. Lagos: CMS Bookshop, 1937. Originalmente compilado na década de 1890 .

${ }^{61}$ Para textos árabes, ver: MARTIN, B. G. A new Arabic history of Ilorin. Research Bulletin, Centre of Arabic Documentation, University of Ibadan, v. 1, n. 2, p. 20-27, 1965; e SMITH, Abdullahi. A little new light on the collapse of the Alafinate of Yoruba. In: SMITH, Abdullahi. A little new light: selected historical writings of Abdullahi Smith. Zaria: Centre for Historical Research, 1987. p. 149-91, especialmente Ahmad b. Abu Bakr Ikokoro, Ta'lîf akhbar al-qurūn min 'umarā' bilad Ilurin (1912), e Waziri Junaidu al-Bukhari, Ta'nìs al-ahibba' fì dhikr umarā' Gwandu māwā al-asfyā'. A importante contribuição de Smith foi também publicada em OLUSANYA, G. O. (ed.). Studies in Yoruba history and culture. Ibadan: University of Ibadan Press, 1983. p. 42-71. Ver também 'ABDULLAH, Muhammad b., emir of Gwandu. Risalà Ila Amìr Yoruba 'Abd al-Salam. In: DANMOLE, Hakeem Olumide Akanni. The frontier emirate, op. cit. appendix II. Para outra documentação, ver: LAW, Robin (Ed.). Contemporary source material for the history of the old Oyo Empire, 1627-1824. Ibadan: Institute of African Studies, 1993. Uma versão revisada (2001) está acessível on-line no site do Shadd (<www.harriettubman.ca>). O jihad é escassamente discutido em trabalhos clássicos da história iorubá, tais como SMITH, Robert S. Kingdoms of the Yoruba. Londres: Methuen, 1969; e AJAYI, J. F. Ade; SMITH, Robert S. Yoruba warfare in the $19^{\text {th }}$ century. Cambridge: Cambridge University Press,
} 
JiHAd Na ÁFrica Ocidental durante a "Era das Revoluçốes":

em direçấo A UM Dí́logo com ERIC HobsbaWm e Eugene GENovese

Paul E. Lovejoy

Califado de Sokoto no século XIX e mais relevante são as várias biografias disponíveis de indivíduos contemporâneos aos eventos.

Samuel Ajayi Crowther, de origem Oyó, foi o primeiro bispo anglicano negro e escreveu extensamente sobre o período, assim como outros missionários da Church Missionary Society em Serra Leoa e na Nigéria. ${ }^{62}$ Ali Eisami Gazirmabe era originalmente de Gazir (daí seu sobrenome), onde foi capturado durante o jihad que atingiu o centro urbano em 18081810. Ele foi vendido como escravo em Katunga, a capital de Oyó, durante as conturbaçóes associadas à revolta de Ilorin em 1817. Para evitar que ele contestasse a sua escravidão, seu proprietário o vendeu para comerciantes envolvidos no tráfico transatlântico. Gazirmabe foi liberado pela marinha britânica sendo enviado para Serra Leoa, onde se tornou conhecido como William Harding. ${ }^{63}$ Há outras narrativas, algumas coletadas por d'Andrada no Brasil e publicadas por Menezes de Drummond em 1819, e ainda aquelas compiladas por Francis de Castelnau em 1849. ${ }^{64}$ Há também os numerosos testemunhos dos envolvidos no levante dos malês de 1835 e de alguns muçulmanos que não fizeram parte nesse movimento. ${ }^{65}$

1964; e mais recentemente a extensa pesquisa de FALOLA, Toyin. Ibadan: foundation, growth and change 1830-1960. Ibadan: Bookcraft, 2012.

${ }^{62}$ Para um relato oficial de Samuel Ajayi Crowther, ver: AJAYI, J. F. Ade. Samuel Ajayi Crowther of Oyo. In: CURTIN, Philip D. (Ed.). Africa remembered: narratives of West Africans from the era of the slave trade. Madison: University of Wisconsin Press, 1965. p. 289-316. Ver também PAGE, Jesse. The black bishop. Londres, 1910; KOPYTOFF, Jean Herskovits. A preface to modern Nigeria. The "Sierra Leonians" in Yoruba, 1830-1890. Madison: University of Wisconsin Press, 1965. p. 285; KOPYTOFF, Jean Herskovits. Bishop Crowther: his life and work. Church Missionary Gleaner, v. 5, p. 10-11, 1878; KOPYTOFF, Jean Herskovits. Letter of Mr. Samuel Crowther to the Rev. William Jowett, Feb. 22, 1837. Church Missionary Record, v. 8, p. 217-223, 1837; KOPYTOFF, Jean Herskovits. A liberated African's account of his slavery, and subsequent course. Church Missionary Gleaner, v. 6, p. 16-18, 1846; e SCHÖN, James Frederick; CROWTHER, Samuel. Journals of the Rev. James Frederick Schon and Mr. Samuel Crowther, p. 371-385, Londres, 1854.

${ }^{63}$ Ali Eisami Gazirmabe, em KOELLE, Sigismund Wilhelm [Londres, 1854]. African native literature. Graz, Áustria: Akademische Druck-u. Verlagsanstalt, 1968. p. 248-256. Ver também SMITH, H. F. C. [Abdullahi]; LAST, D. M.; GUBIO, Gambo. Ali Eisami Gazirmabe of Bornu. In: CURTIN, Philip D. (Ed.). Africa remembered, op. cit. p. 199-216. Para outros relatos dos ex-escravos hausas e nupes em Serra Leoa, ver: FYFE, Christopher. A history of Sierra Leone. Londres, 1962. p. 66, 138, 170, 231, 234, 424 (hausa) e 170, 231, 289, 293, 320 (nupe).

${ }^{64}$ DRUMMOND, Menezes de. Lettres sur l'Afrique ancienne et moderne. Journal des Voyages, v. 32, p. 290-324 [sic: 190-224], 1826; e CASTELNAU, François de. Renseignements sur l'Afrique centrale et sur une nation d'hommes à queue qui s'y trouverait, d'après le rapport des nègres du Soudan, esclaves à Bahia. Paris, 1851. Ver também MISRAH, Muhammad. Narrative of a journey from Egypt to the western coast of Africa, by Mahomed Misrah. Communicated by an officer serving in Sierra Leone. The Quarterly Journal, v. 6, p. 15-16, out. 1822 .

${ }^{65}$ SMITH, Marcia. The male uprising in Bahia, 1835: mini-biographies of leaders and others accused. Dissertação (mestrado) - York University, Toronto, 1998; CAIRUS, José. Instrumentum vocale, mallams e alufás, op. cit. p. 128-164; CAIRUS, José. Jihad, cativeiro e redenção, op. cit.; e MELLO, Priscilla. Leitura, encantamento e rebeliāo, op. cit. Também consultei REICHERT, Rolf. L'insurrection d'esclaves de 1835 à la lumière des documents árabes des archives publiques de l'état de Bahia (Bresil). Bulletin de l'Institut Fondamental d'Afrique Noire, sér. B, v. 29, n. 1-2, p. 99-104, 1967; e REICHERT, Rolf. Os documentos Árabes do arquivo público do estado da Bahia. Salvador: Universidade Federal da Bahia, Centro de Estudos Afro-Orientais, 1979. As transcriçôes judiciais dos processos após a revolta de 1835 contêm referências a 
JiHAd Na ÁFrica Ocidental durante a "Era das Revoluçốes":

em direçấo A UM Dí́logo com ERIC HobsbaWm e Eugene GENovese

Paul E. Lovejoy

Rufino José Maria, cujo nome africano, Abuncare, provavelmente indica Abu, abreviação de Abubakar, e "Ncare”, contração de Birnin Konni (N'care = N'Konni), uma cidade fortificada no norte de Sokoto, não estava envolvido na revolta na Bahia porque ele estava no sul do Brasil na época. ${ }^{66}$ Há também o relato de um imã de Bagdá que visitou o Rio de Janeiro, Bahia e Pernambuco no início da década de 1860 e descreveu a comunidade muçulmana no Brasil. ${ }^{67}$ Além disso, outros relatos sobre a escravidão no Sudão Central na primeira metade do século XIX fornecem informações essenciais para o entendimento de como os jihad afetaram a instituição da escravidão. ${ }^{68}$ Em suma, as fontes primárias são abundantes e muitas são de fácil acesso. Apesar das diferentes interpretaçôes das fontes secundárias sobre as causas, a evolução e a repercussão do jih ad, essas diferenças são fruto do processo e enriquecem a historiografia, não devendo, portanto, ser ignoradas. Metodologicamente, devemos seguir os trabalhos apresentados por Peter Linebaugh e Marcus Rediker, Jane Landers, James Sweet, Rebecca Scott e Jean M. Hébrard, Walter Hawthorne, e Paul Lovejoy e incluir mais bibliografias nas nossas análises. ${ }^{69}$

outros documentos. Ver, por exemplo: Anais do Arquivo do Estado da Bahia, v. 38, p. 61-63, 1968, e v. 40, p. 42-43, 1971; MONTEIL, Vincent. Analyse de 25 documents árabes desés de Bahia (1835). Bulletin de l'Institut Fondamental d'Afrique Noire, sér. B, v. 29, n. 1-2, p. 88-98, 1967.

${ }^{66}$ REIS, João José; GOMES, Flávio dos Santos; CARVALHO, Marcus J. M. de. África e Brasil entre margens: aventuras e desventuras do africano Rufino José Maria, c. 1822-1853. Revista Estudos Afro-Asiáticos, v. 4, p. 257-302, 2005; REIS, João José; GOMES, Flávio dos Santos; CARVALHO, Marcus J. M. de. O alufá Rufino: tráfico, escravidão e liberdade no Atlântico Negro (c. 1823 - c. 1853). Sáo Paulo: Companhia das Letras, 2010. Um problema similar é encontrado em REIS, João José. Domingos Pereira Sodré, un prêtre africain dans la Bahia du XIX siècle. In: HEBRARD, Jean (Ed.). Brésil quatre siècles d'esclavage: nouvelles questions, nouvelles recherches. Paris: Karthala, 2012. p. 165-216.

${ }^{67}$ Ver ADDOUN, Yacine Daddi; SOULODRE-LA France, Renée. The Amusement of the Foreigner. (Draft version). Toronto, Canadá: The Nigerian Hinterland Project/York University, 2001, disponível em <http://www. yorku.ca/nhp/shadd/baghdadi.pdf >. Acesso em: 10 jun. 2014; ou ver FARAH, Paulo (org.). Deleite do estrangeiro em tudo o que é espantoso e maravilhoso: estudo de um relato de viagem Bagdali. Rio de Janeiro: Fundação Biblioteca Nacional; Argel: Bibliotèque Nationale d'Algérie; Caracas: Biblioteca Nacional de Caracas, 2009.

${ }^{68}$ LOVEJOY, Paul E. Biographies of enslaved Muslims from the Central Sudan in the nineteenth century. In: BOBBOYI, H.; YAKUBU, A. M. (Ed.). The Sokoto Caliphate, op. cit. v. 1, p. 187-216. Sean Kelley e eu estamos construindo um banco de dados de biografias que vai ser base para um estudo da escravização na África Ocidental na primeira metade do século XIX.

${ }^{69}$ LINEBAUGH, Peter; REDIKER, Marcus. The many-headed hydra: sailors, slaves, commoners, and the hidden history of the revolutionary Atlantic. Boston: Beacon Press, 2000; LANDERS, Jane G. Atlantic Creoles in the age of revolutions, op. cit.; SCOTT, Rebecca; HÉBRARD, Jean M. Freedom papers: an Atlantic odyssey in the age of emancipation. Cambridge, MA: Harvard University Press, 2012; HAWTHORNE, Walter. "Being now, as it were, one family": shipmate bonding on the slave vessel Emilia, in Rio de Janeiro and throughout the Atlantic World. Luso-Brazilian Review, v. 45, n. 1, p. 53-77, 2008; HAWTHORNE, Walter. From Africa to Brazil: culture, identity, and an Atlantic slave trade, 1600-1830. Nova York: Cambridge University Press, 2010; SWEET, James H. Recreating Africa: culture, kinship, and religion in the African-Portuguese world, 1440-1770. Chapel Hill: University of North Carolina Press, 2003; SWEET, James H. Mistaken identities? Olaudah Equiano, Domingos Álvares, and the methodological challenges of studying the African diaspora. American Historical Review, v. 114, n. 2, p. 279-306, 2009; SWEET, James H. Domingos Alvares, African healing, and the intellectual history of the Atlantic World. Ver ainda LAW, Robin; MANN, Kristin. West Africa in the Atlantic community: the case of the slave coast. William and Mary Quarterly, v. 56, n. 2, p. 307- 
JiHAd Na ÁFrica Ocidental durante a "Era das Revoluçốes":

em direçấo A UM Dí́logo com ERIC Hobsbawm e Eugene Genovese

Paul E. Lovejoy

Em seu Kitāb al-Salāt, escrito na Jamaica por volta da década de 1820, Kaba Saghanughu exibiu um conhecimento específico da elite letrada da África Ocidental. Seu próprio nome indica conexão com uma das famílias mais eruditas no Sudão Ocidental. ${ }^{70}$ Quando um membro da elite era capturado, geralmente a família o resgatava, o que parece não ter sido seu caso. O pai de Kaba Saghanughu, chamado 'Abd al-Qadiri, era "um proprietário de terras abastado, dono de 140 escravos, várias vacas e cavalos, produtor de grande quantidade de algodão, arroz e outros cereais para seu sustento" ${ }^{71}$ Kaba era originário de Bouka, localizada a aproximadamente $20 \mathrm{~km}$ ao sul de Dingueraye, um dos afluentes do rio Níger. Ele foi instruído nos temas básicos da educação islâmica: o Alcorão, hadīth, fiqh, e referiu-se aos Șahīḥs dos muçulmanos e Bukhari, ambos livros sobre a tradição do profeta Maomé, o hạaīth, bem como ao Kitāb al-Munabbihāt. Ele também citou a influência do sheik Bābā al-Fakiru, provavelmente um de seus professores, assim como seu tio, Mohammed Batoul. ${ }^{72}$ O estilo de erudição ao qual Kaba foi exposto seguia o modelo da irmandade da Qadiriyya, que incluía um currículo básico cobrindo a Muwatta’ de Mālik, o Shifä’ de Qāḍī 'Iyaụ b. Mūsā e o Tafsir al-Jalālayn. O motivo pelo qual Kaba não foi resgatado é um mistério, afinal a lei e a prática islâmica defendiam tal direito, apesar de haver outros casos de membros de famílias abastadas que também permaneceram em cativeiro. ${ }^{73}$ Nicholas Sa'id é outro caso

334, 1999; e LOVEJOY, Paul E. Biographies of enslaved Muslims from the Central Sudan in the nineteenth century, op. cit. p. 187-216; REIS, João José. Domingos Sodré, um sacerdote africano. Escravidão, liberdade e Candomblé na Bahia do século XIX. São Paulo: Companhia das Letras, 2008; REIS, João José; GOMES, Flávio dos Santos; CARVALHO, Marcus Joaquim. O alufá Rufino, op. cit.; FERREIRA, Roquinaldo, Crosscultural exchange in the Atlantic World: Angola and Brazil during the era of the slave trade. s.l.: Cambridge University Press, 2012; MOTT, Luiz R. B. Rosa Egipcíaca: uma santa africana no Brasil. Rio de Janeiro: Bertrand Brasil, 1993; CANDIDO, Mariana. Aguida Gonçalves da Silva, une dona à Benguela à fin du XVIIIe siècle, Brésil(s). Sciences Humaines et Sociales, v. 1, p. 33-54, 2012; CANDIDO, Mariana P. African freedom suits and Portuguese vassal status: legal mechanisms for fighting enslavement in Benguela, Angola, 1800-1830. Slavery \& Abolition, v. 32, n. 3, p. 447-459, 2011.

${ }^{70}$ WILKS, Ivor. The transmission of Islamic learning in the Western Sudan. In: GOODY, Jack (Ed.). Literacy in traditional societies. Cambridge: Cambridge University Press, 1968. p. 162-197; e WILKS, Igor. The Saghanughu and the spread of Maliki law: a provisional note. Research Review, Institute of African Studies, University of Ghana, v. 2, n. 3, 1966.

${ }^{71}$ MADDEN, R. R. A twelvemonth's residence in the West Indies, during the transition from slavery to apprenticeship [1835]. Westport, CN: Negro University Press, 1970. v. 2, p. 135.

${ }^{72}$ ADDOUN, Yacine Daddi; LOVEJOY, Paul E. Muḥammad Kabā Saghanughu and the Muslim community of Jamaica. In: LOVEJOY, Paul E. Slavery on the frontiers of Islam, op. cit. p. 201-202.

${ }^{73}$ Sobre resgate, ver: LOFKRANTZ, Jennifer. Intellectual discourse in the early Sokoto Caliphate: the triumvirate's opinions on the issue of ransoming c. 1810. International Journal of African Historical Studies, v. 45, n. 3, p. 385-401, 2012; LOFKRANTZ, Jennifer; OJO, Olatunji. Slavery, freedom, and failed ransom negotiations in West Africa 1730-1900. Journal of African History, v. 53, n. 1, p. 25-44, 2012; LOFKRANTZ, Jennifer. Protecting freeborn Muslims: the Sokoto Caliphate's attempts to prevent illegal enslavement and its acceptance of the strategy of ransoming. Slavery and Abolition, v. 32, n. 1, p. 109-127, 2011; LOFKRANTZ, Jennifer. Ransoming of captives in the Sokoto Caliphate in the nineteenth century. In: MONTANA, Ismael Musah; LOVEJOY, Paul E. (Ed.). Slavery, Islam and diaspora, op. cit. p. 125-137; e LOFKRANTZ, Jennifer. Ransoming policies and practices in the Western and Central Biläd al-Südān c1800-1910. Tese (Ph.D.) — York University, Toronto, 2008. 
JiHAd Na ÁFrica Ocidental durante a "Era das Revoluçốes":

em direçấo A UM Dí́logo com ERIC HobsbaWm e Eugene Genovese

Paul E. Lovejoy

de um muçulmano escravizado que não foi resgatado do cativeiro. Seu pai, Barca Gana, também era escravo e ocupava a posição de general no governo de Shehu al-Kanemi em Borno. Apesar do prestígio, o pai não comprou a liberdade do filho. ${ }^{74} \mathrm{O}$ filho, de origem bagirmi devido à ascendência materna, recebeu boa educação, o que elevava seu valor como escravo, e chegou a trabalhar como agente de um comerciante no Egito e a acompanhar um diplomata russo em São Petersburgo, onde ele aparentemente foi liberto antes de viajar para a América do Norte e lutar na Guerra Civil Americana ao lado do governo dos Estados Unidos - ou seja, no exército que representava os interesses dos estados do norte. Outro caso de muçulmano não resgatado foi o de Richard Pierpoint, nascido em Fuuta Bundu em 1744. Pierpoint foi escravizado quando as forças de Segu invadiram Fuuta Bundu. Vendido como escravo, Pierpoint foi levado para a América do Norte, mas escapou da escravidão ao se alistar no exército britânico durante a revolução americana. Já em idade avançada, Pierpoint, que era fulbe, apresentou uma petição às autoridades britânicas em 1821 com o objetivo de regressar à sua terra natal. Sua petição, no entanto, foi recusada e ele morreu na província do Alto Canadá, correspondente à província de Ontário no mapa atual. ${ }^{75}$

A identidade étnica no Sudão Central, incluindo regióes de Oyó, era muito complexa. As pessoas falavam mais de uma língua e muitas vezes aprendiam novos idiomas. A origem dos indivíduos correspondia aos lugares de nascimento de seus pais ao mesmo tempo que se identificavam com as cidades próximas ao seu lugar de residência, entre elas as cidades fortificadas de Kano, Katsina, Bebeji, Kura e Zaria. No contexto muçulmano e nas identificações dos iorubás e dos hausas, o local de origem foi essencial no processo de afirmação de identidade, porém essa fazia referência tanto ao local de residência do indivíduo como à aldeia ou cidade de nascimento dos seus pais. ${ }^{76}$ Escarificaçóes faciais e corporais eram praticadas como um meio de identificação, inclusive como proteção contra a escravidão, além de representarem rituais de solidariedade da comunidade. ${ }^{77}$ Os nomes utilizados, assim como os diferentes nomes que uma pessoa poderia assumir ao longa da vida, indicavam

\footnotetext{
${ }^{74}$ SA'ID, Nicholas. The autobiography of Nicholas Said; a native of Bornou, Eastern Soudan. Memphis: Shotwell \& Co., 1873; e SA'ID, Nicholas. A native of Bornoo. Atlantic Monthly, p. 485-495, 1867. Para Barca Gana, BRENNER, Louis. The Shehus of Kukawa, op. cit.

${ }^{75}$ MEYLER, David; MEYLER, Peter. A stolen life: searching for Richard Pierpoint. Toronto: Natural Heritage Books, 1999.

${ }^{76}$ LOVEJOY, Paul E. The urban background of enslaved Muslims in the Americas, op. cit. p. 347-372.

${ }^{77}$ LOVEJOY, Paul E. Scarification and the loss of history in the African diaspora. In: APTER, Andrew; DERRY, Lauren (Ed.). Activating the past historical memory in the Black Atlantic. Newcastle: Cambridge Scholarly Publishing, 2010. p. 99-138. Também ver: KEEFER, Katrina. Scarification and identity in the liberated Africans department registers 1814-1815. Canadian Journal of African Studies, no prelo; e LOVEJOY, Henry. Old Oyo influences on the transformation of Lucumí identity in colonial Cuba, op. cit. Atualmente estou envolvido em um projeto de pesquisa com Abubakar Babajo Sani, do Departmento de História da Universidade Musa Yar'Adua, em Katsina, dedicado ao registro de imagens visuais de escarificaçóes e penteados nos emirados centrais do Califado de Sokoto. O projeto está sendo desenvolvido sob os auspícios da Cátedra de Pesquisa em História da Diáspora Africana do Canadá e da Universidade Usman Musa Yaradua.
} 
JiHAd Na ÁFrica Ocidental durante a "Era das Revoluçốes":

associaçóes a certas linhagens assinalando a posição social e a crença religiosa. ${ }^{78}$ Quando falo sobre uma metodologia que prioriza uma compreensão étnica, meu objetivo é desvendar a sobreposição de identidades. Ainda que as pessoas se identificassem como muçulmanos, essa identidade religiosa também implicava uma associação a um lugar de origem, de preferência um Estado islâmico, muitas vezes evidente pelas escarificaçóes espalhadas pelo corpo e pelos penteados. Ser muçulmano e livre de nascimento era visivelmente reconhecido por meio desses sinais que os distinguia da população escravizada.

Os muçulmanos envolvidos na revolta na Bahia falavam pelo menos o iorubá e o hausa, e muitas vezes idiomas como o nupe, o kanuri, além de outros, tinham certo conhecimento de árabe, afinal deveriam rezar nesse idioma uma vez que as oraçóes não poderiam ser feitas em qualquer outra língua. No caso dos homens muçulmanos, provavelmente sabiam ler e escrever em árabe. Ao chegar à Bahia, entretanto, podiam identificar-se ou ser identificados como iorubás, pois esse idioma era utilizado como língua franca. Para aqueles que falavam o iorubá, independentemente de seu lugar de origem, era fácil assumir uma nova identidade, sobreposta às outras. No caso de Ali Eisami que falava pelo menos kanuri, hausa e iorubá e escreveu sua biografia em inglês e em kanuri, é evidente que ele podia assumir várias identidades, dependendo do contexto. A habilidade de falar várias línguas e circular em várias comunidades dificulta qualquer tentativa simplista de associar a etnia exclusivamente com língua. Caso semelhante foi o de Dorogu, escravizado no Borno Ocidental, e falante do hausa como língua materna, mas também fluente em kanuri, além de ter aprendido o inglês e o alemão. Ele escreveu sua biografia em hausa e forneceu numerosos fragmentos históricos e poesias na mesma língua, posteriormente traduzidos para o inglês. Ali Eisami e Dorugu também estudaram árabe na escola corânica e sabiam o idioma o suficiente para rezar e manter uma conversa. $\mathrm{O}$ risco é confundir etnia com língua sem uma análise mais aprofundada sobre outros elementos que constituíam as identidades.

O jihad influenciou a migração de africanos escravizados para as Américas de dois modos: temporalmente dividiu a população escravizada e deportada entre o século XVIII e o século XIX; e geograficamente diferenciou indivíduos oriundos do Sudão Ocidental e do Sudão Central, capturados em momentos e movimentos distintos. Os especialistas sobre os muçulmanos na América do Norte e no Caribe anglófono e francófono (com exceção de Trinidade), em grande parte se dedicam a histórias de vida de pessoas que vieram do Sudão Ocidental durante o século XVIII. ${ }^{79}$ Outro conjunto de narrativas corresponde a indivíduos

${ }^{78}$ ELTIS, David; HALBERT, Martin; MISEVICH, Philip (Ed.). The African origins project. Disponível em: <www.african-origins.org>. Ver também SCHWARZ, Suzanne. Extending the African names database: new evidence from Sierra Leone. African Economic History, v. 38, p. 137-163, 2010; e LOVEJOY, Henry B. Transformation of Lucumí identity in colonial Cuba, op. cit. p. 17-18, 27-33, 37-38.

79 Ver, por exemplo: DIOUF, Sylviane. Servants of Allah, op. cit.; GOMEZ, Michael. Muslims in early America, op. cit. p. 671-710; GOMEZ, Michael. Black crescent. Ver também o trabalho negligenciado sobre Richard Pierpoint, que veio de Fuuta Bundu e lutou ao lado dos britânicos na Guerra de Independência Americana, formando depois um regimento negro que ajudou a prevenir a conquista americana do Canadá 
capturados no Sudão Central durante o século XIX, embora haja exceçóes para ambos os séculos e regiốes. Essa divisão temporal reflete os padrôes de mudança histórica na África Ocidental, a primeira ocorrendo no século XVIII e em grande parte confinada ao oeste do Sudão, enquanto a segunda fase centrou-se na região central do Sudão no início do século XIX, mas com repercussóes em todo o Sudão Ocidental. Os estudos sobre a revolta dos malês na Bahia, a formação da cultura iorubá em Cuba no século XIX e as comunidades muçulmanas e iorubás em Trinidade e Serra Leoa têm suas origens no movimento do jihad do Sudão Central no início do século XIX. Em ambos os casos, a "era das revoluções" seguiu o mesmo padrão dos jihad, com algumas diferenças importantes. Não houve distinção clara entre "rebeliâo" e "revolução", como proposto por Genovese, cuja análise negligenciou os eventos da história africana. Reaçóes à escravidão nas Américas eram mais complexas do que a divisão binária entre "rebeliāo" e "revolução", que ignora qualquer perspectiva de fundo religioso influenciada pelo Islá. O período entre o final do século XVIII e o início do século XIX foi um momento de intensificação do jihad na África Ocidental, apesar desse fato não ter sido levado em consideração por Genevese. A cronologia da "era das revoluções" no mundo atlântico e a do movimento do jihad na África Ocidental se sobrepóem.

Enquanto a primeira fase da influência islâmica resultou, principalmente, no tráfico para a América do Norte e o Caribe anglófono e francófono, a segunda fase resultou na deportação de cativos para a Bahia e Cuba. Em determinados momentos, essas migraçóes e períodos se sobrepunham em relação a São Domingos. Da mesma forma que em São Domingos houve uma revolução, o mesmo podemos dizer dos acontecimentos no Sudão Central. Eram movimentos paralelos que passaram por vários momentos e resultaram em mudanças que nem sempre estavam de acordo com a "era das revoluçóes" em geral. O silêncio histórico surge, em grande parte, do fracasso em compreender um mundo atlântico que poderia incorporar acontecimentos na África como parte de uma experiência atlântica. O conceito da "era das revoluçôes" não incorporou um movimento revolucionário de cunho religioso como os jihad, apesar de sua importância e do significado que teve para o comércio transatlântico de escravos. O diálogo com a contribuição de Genovese e Hobsbawm requer uma revisão de conceitos, principalmente no que diz respeito à definição de "revolução" e de sua relevância como fator explicativo para os movimentos desse período.

As conexôes entre os diferentes mundos das revoluções têm de ser analisadas. A revolução em São Domingos eliminou, de maneira brusca, os contatos entre a colônia francesa com Porto Novo, de onde chegavam notícias e influências dos eventos ocorridos no Sudão Central. O principal negociante de Porto Novo, Pierre Tamata, é um agente-chave para entender as conexóes entre essas duas localidades que, até então, estavam sob influência francesa. Tamata, muçulmano de origem hausa, tinha sido educado na França e atuava como 
JiHAd Na ÁFrica Ocidental durante a "Era das Revoluçốes":

em direçấo A UM Dí́logo com ERIC HobsbaWm e Eugene GENovese

Paul E. Lovejoy

o principal fornecedor de escravos para os comerciantes franceses em Porto Novo, durante as décadas de 1780 e 1790. Poucos conhecem a importância de Tamata e de sua família no controle da comunidade muçulmana e no comércio em Porto Novo na virada do século XIX, porém ele mantinha uma ligação clara com o litoral e o interior da África Ocidental através de seus contatos no interior de Oyó no Sudão Central. ${ }^{80} \mathrm{E}$, de fato, a atuação de Tamata no comércio transatlântico enfatiza uma das denúncias graves que Uthman Dan Fodio fez sobre a venda de muçulmanos para os comerciantes cristãos no litoral através dos mercados de Oyó, uma das principais justificativas para o movimento do jihad. ${ }^{81}$

$\mathrm{O}$ papel dos muçulmanos na resistência à escravidão nas Américas deve ser reavaliado. As primeiras contribuiçóes de estudiosos sobre o assunto têm sido largamente ignoradas ou mal interpretadas. Schwartz foi pioneiro em enfatizar a ligação entre as revoltas na Bahia e a migração hausa, porém trabalhos posteriores enfatizaram sua análise sobre os “iorubás" ou mais precisamente sobre os "nagôs", sem desconstruir o significado desses termos em contextos históricos específicos. Só recentemente, com estudo de Manuel Barcia que analisa o significado de termos étnicos em Cuba, esse paradigma foi contestado. Como Barcia observa, o jihad teve um impacto dramático sobre Cuba e Bahia, embora o autor não documente esse impacto. ${ }^{82}$ Por outro lado, a análise de Henry B. Lovejoy dos registros de embarcaçóes e da Comissão Mista anglo-cubana que operava em Havana revelou que os não muçulmanos de origem Oyó, incluindo os iorubás das dependências de Oyó, destruídas após a revolta de

\footnotetext{
${ }^{80}$ Para uma discussão acerca de Pierre Tamata, consultar: VERGER, Pierre. Trade relations between the Bight of Benin and Bahia, op. cit. p. 186-190; ADAMS, John. Remarks on the country extending from Cape Palmas to the river Congo. Londres, 1823. p. 82-87. Tamata é também discutido em LOFKRANTZ, Jennifer; LOVEJOY, Paul E. Crossing network boundaries: Islamic law and commerce from Sahara to Guinea shores.
} No prelo.

${ }^{81}$ Para informaçôes sobre o comércio de Oyó através de Porto Novo, ver: MORTON-WILLIAMS, Peter. The Oyo Yoruba and the Atlantic slave trade, 1670-1830. Journal of the Historical Society of Nigeria, v. 3, n. 1, p. 25-45, 1964. Badagry se tornou o principal rival para o comércio de Oyó e, consequentemente, para a ascendência de Tamata. Ver: SORENSEN, Caroline. Badagry 1784-1863. The political and commercial history of a pre-colonial lagoonside community in South West Nigeria. Tese (Ph.D.) - University of Stirling, Stirling, 1995; e SORENSEN-GILMOUR, C. Slave-trading along the lagoons of South-West Nigeria: the case of Badagry. In: LAW, Robin; STRICKRODT, Silke (Ed.). Ports of the slave trade (bights of Benin and Biafra). Stirling: Centre of Commonwealth Studies, 1999. p. 84-95. Ver também SILVA JR, Carlos da. Ports of the Bight of Benin and the legal slave trade to Bahia, Brazil, 1750-1815, trabalho não publicado apresentado no Encontro Anual da Associação Canadense de Estudos Africanos, na Carleton University, em Ottawa, de 1a 3 de maio de 2013; ANDERSON, Richard; BORUCKI, Alex; SILVA, Daniel D. da; ELTIS, David; LACHANCE, Paul; MISEVICH, Philip; OJO, Olatunji. Using African names to identify the origins of captives in the transatlantic slave trade: the registers of liberated africans, 1808-1862. History in Africa, v. 40, p. 165-191, 2013; OJO, Olatunji. Child slaves in the "Nigerian" hinterland, 1725-1865. Slavery and Abolition, v. 33, p. 417-434, 2012.

${ }^{82}$ BARCIA, Manuel. Un Islamic Atlantic revolution, op. cit. p. 6-18. Ver também BARCIA, Manuel. West African Islam in colonial Cuba, op. cit. Barcia se refere aos muçulmanos como "africanos islamizados" por motivos não explicados. Porém, ele não faz referência a "europeus cristianizados". Havia africanos muçulmanos no Sudão Ocidental e Central desde pelo menos o século XI, ou seja, quatrocentos anos antes do início do comércio transatlântico e, portanto, contemporâneos do domínio muçulmano da península Ibérica. 
JiHAd Na ÁFrica Ocidental durante a "Era das Revoluçốes":

em direçấo A UM Dí́logo com ERIC Hobsbawm e Eugene Genovese

Paul E. Lovejoy

1817 em Ilorin e a expansão do jihad, foram enviados predominantemente a Cuba. Segundo H. B. Lovejoy, os muçulmanos iorubás, hausas e de outras etnias foram enviados para a Bahia. ${ }^{83}$ As implicaçôes dessa divisão do comércio transatlântico desafiam uma perspectiva eurocêntrica, como as de Hobsbawm e Genovese, que negligenciaram a importância dos jihad na "era das revoluçôes". A influência muçulmana se estende a outros locais e contextos, além de Cuba e Brasil, tais como as agitaçôes da população muçulmana em Serra Leoa na década de $1830,{ }^{84}$ as tentativas dos muçulmanos em Trinidade de retornar à África Ocidental durante as década de 1820 e 1830, ou ainda o papel dos muçulmanos na insurreição na Jamaica em 1831-1832. ${ }^{85}$

As grandes revoluçôes na Europa Ocidental e nas Américas foram de caráter republicano, como uma reação ao ancien régime e a monarquia despótica, exceto no caso da Grá-Bretanha, cuja monarquia constitucional sob a liderança do parlamento estava estabelecida. $\mathrm{Na}$ África Ocidental, o movimento de jihad que assolou a regiáo foi uma resposta aos governos despóticos centralizados nas mãos de elites militares. A consolidação de governos islâmicos estava baseada no apoio das lideranças religiosas e de funcionários do Estado, alguns dos quais escravos. ${ }^{86} \mathrm{O}$ Estado guiava-se pela lei islâmica e pelo precedente da liderança herdada. Devido a essas características, é essencial determinar se havia ou não um imã na Bahia durante a revolta malê. O imá é figura-chave no contexto do jihad e da organizaçáo da comunidade islâmica, afinal é ele quem determina se uma guerra é legítima ou não. No caso da Bahia, a melhor evidência vem de Nina Rodrigues, que, no final do século XIX, declarou ter aprendido sobre o levante malê com o então imã da Bahia que, por sua vez, havia obtido seus conhecimentos com aquele que era o imã no momento da insurreição de $1835 .{ }^{87}$

\footnotetext{
${ }^{83}$ LOVEJOY, Henry. Old Oyo influences in colonial Cuba, op. cit.

${ }^{84}$ Para as açôes de muçulmanos Aku em Serra Leoa, ver: PETERSON, John. Province of freedom: a history of Sierra Leone, 1787-1870. Londres, 1969. p. 93, 212-217; e FYFE, Christopher. A history of Sierra Leone. Londres, 1962. p. 170, 186-187, 204, 212, 215; FILE, C. Magbaily. A nationalist history of Sierra Leone. Freetown, 2011; JALLOH, Alusine; SKINNER, David E. (Ed.). Islam and trade in Sierra Leone. Trenton, NJ: Africa World Press, 1997; MCGOWAN, Winston. The development of European relations with Futa Jallon and the foundation of French colonial rule, 1794-1897. Tese (Ph.D.) - University of London, Londres, 1978.

${ }^{85}$ Acerca de Trinidad, ver: LOVEJOY, Paul E.; TROTMAN, David. Community of believers: Trinidad Muslims and the return to Africa, c. 1810-1850. In: LOVEJOY, Paul E. Slavery on the frontiers of Islam, op. cit. p. 221-234. Para a Jamaica e a alegada existência do wathiqat de Kaba Saghanughu, que veio do Fuuta Jallon, ver: ADDOUN, Daddi; LOVEJOY, Paul E. Muhammad Kābā Saghanughu and the Muslim community of Jamaica, op. cit. p. 201-220; e ADDOUN, Daddi; LOVEJOY, Paul E. The Arabic manuscript of Muhammad Kaba Saghanughu of Jamaica, c. 1820. In: PAUL, Annie (Ed.). Creole concerns: essays in honour of Kamau Brathwaite. Kingston: University of the West Indies Press, 2007. p. 313-341.

${ }^{86}$ STILWELL, Sean. Paradoxes of power: the Kano 'Mamluks' and male royal slavery in the Sokoto Caliphate, 1804-1903. Portsmouth, NH: Heinemann, 2004; STILWELL, Sean. Power, honour and shame: the ideology of royal slavery in the Sokoto Caliphate. Africa, v. 70, n. 3, p. 394-421, 2000; STILWELL, Sean. "Amana" and "Asiri": royal slave culture and the colonial regime in Kano, 1903-1926. Slavery and Abolition, v. 19, n. 2, p. 167-188, 1998.

${ }^{87}$ De acordo com o imã de Salvador na década de 1890, o imã ao tempo da revolta era Abubakar, que é um nome haussá. Ver RODRIGUES, Raymundo Nina. Os africanos no Brasil. São Paulo, 1932. p. 109-110.
} 


\section{Além do diálogo com Hobsbawm e Genovese}

Os debates intelectuais sobre a escravidão refletem as perspectivas de seus autores, situados em contextos históricos e culturais específicos. Na Europa Ocidental, o racionalismo ilustrado utilizou o discurso da raça e da ciência para legitimar a escravidão, definindo os africanos como "naturalmente" inferiores. Inevitavelmente, os defensores da abolição também utilizaram argumentos racializados, inicialmente proibindo a importação de africanos escravizados nas Américas e posteriormente libertando escravos negros, porém evitando qualquer possibilidade de migração de negros livres, a não ser em regimes de trabalho contratado, em condiçôes similares à escravidão. No contexto islâmico, a escravidão era legitimada por meio de um discurso religioso e não racial, fazendo uso de categorias culturais e sociais e não de distinçóes biológicas ou fenotípicas. Tanto os debates islâmicos como europeus alegavam universalismo, embora cada um se apoiasse em conhecimentos culturalmente definidos. A abolição do tráfico de escravos, a luta para a emancipação, a explosão do sistema de trabalho forçado e a compensaçâo financeira aos ex-proprietários pela perda da "propriedade" devem ser compreendidos como produtos do iluminismo europeu e da preocupação com os "direitos humanos", articulada na Revoluçáo Francesa e no movimento de reforma cristá baseada na Grä-Bretanha. Análises parciais ignoram debates intelectuais na África Ocidental acerca da legitimidade da escravidáo e da liberdade dos muçulmanos desde o nascimento. No caso de muçulmanos escravizados em algum momento de sua vida, o ônus da prova recaía sobre aquele que reivindicava o direto de propriedade sob um indivíduo. O recrudescimento da escravidão nos Estados jihadistas, particularmente no século XIX, coincide com a expansão da demanda por escravos em Cuba, no Brasil e no sul dos Estados Unidos, a chamada "segunda escravidão", de acordo com Tomich. ${ }^{88}$ Ao incluirmos o movimento do jihad na "era das revoluçôes" devemos considerar as especifidades do fim da escravidão, seja de forma radical e abrupta, como em São Domingos, ou de forma gradual, como nas colônias britânicas. Ao mesmo tempo, devemos contrabalançar o fim da escravidão em alguns territórios com a sua expansão em outros, tais como o sul dos Estados Unidos, Cuba, Brasil e os Estados do jihad da África Ocidental.

Ainda não estáo claros os motivos pelos quais a história atlântica continua sem incorporar a história africana no centro de sua análise. Historiadores como Walter Hawthorne, James Sweet, Roquinaldo Ferreira, Rebeca Scott, Paul Lovejoy, Mariana Candido colocam a África no centro de seus estudos e seguem biografias de indivíduos em contextos históricos específicos, da melhor forma que pode ser reconstruída. Em comum, esses autores enfatizam

Nina Rodrigues baseou seu estudo em informaçóes coletadas entre 1890 e sua morte, em 1906. Ver também VERGER, Pierre. Trade Relations between the Bight of Benin and Babia, 17 $17^{\text {th }} 19^{\text {th }}$ century, op. cit. p. 300, 307. Reis discute outros clérigos que ele considera que pudessem ser o líder, mas náo inclui Abubakar entre eles. Ver REIS, João José. Slave rebellion in Brazil, op. cit. p. 130.

${ }^{88} \mathrm{TOMICH}$, Dale. Through the prism of slavery, op. cit. 
JiHAd Na ÁFrica Ocidental durante a "Era das Revoluçốes":

em direçấo A UM Dí́logo com ERIC HobsbaWm e Eugene Genovese

Paul E. Lovejoy

o lugar da África, oferecendo uma perspectiva alternativa sobre o Atlântico, enfatizando o contexto africano de maneiras muito específicas. ${ }^{89}$ Esses esforços de reconstrução histórica exigem uma relação direta entre as etnias manifestadas na diáspora como "nação" ou "país de origem" com locais específicos na África e seus significados em circunstâncias históricas determinadas. Como as pessoas chegaram ao seu destino nas Américas? E em que contexto foram escravizadas e vendidas como escravos? Como a África Centro-Ocidental, a baía de Biafra e a África Oriental foram capazes de fornecer dois terços de todas as pessoas escravizadas enviadas às Américas no século XIX? As análises atlânticas devem estar bem informadas e reconhecer o contexto histórico da migração forçada de escravos e o impacto que resultou na África. É necessário compreender o contexto em que as pessoas foram capturadas, escravizadas e deportadas. Tal abordagem tem implicaçôes profundas sobre como a África deve ser integrada nos estudos do mundo atlântico e, principalmente, a relaçáo de diferentes partes do continente africano com a "era das revoluçóes". ${ }^{90}$

\footnotetext{
${ }^{89}$ LAW, Robin; LOVEJOY, Paul E. (Ed.). The biography of Mahommah Gardo Baquaqua: his passage from slavery to freedom in Africa and America. Princeton, NJ: Markus Wiener Publishers, 2001; Daddi Addoun and Lovejoy, "Muhammad Kābā Saghanughu," 201-20; ADDOUN, Yacine Daddi; LOVEJOY, Paul E. Muḥammad Kabā Saghanughu and the Muslim community of Jamaica, op. cit. p. 313-341; LOVEJOY, Paul E. Les origines de Catherine Mulgrave Zimmermann: considérations méthodologiques. Cahiers des Anneaux de la Mémoire, v. 14, p. 247-263, 2011.

${ }^{90} \mathrm{Em}$ 1997, minha própria crítica foi publicada on-line, mas foi posteriormente removida da internet até ser recuperada pelo website do Tubman Institute. Todavia, a crítica ainda permanece. Ver "The African diaspora: revisionist interpretations of ethnicity, culture and religion under slavery", originalmente publicado na revista on-line editada por Patrick Manning, Studies in the world history of slavery, abolition and emancipation, v. 2, n. 1, 1997, que misteriosamente desapareceu. O artigo pode ser encontrado em: <www.tubmaninstitute.ca>.
} 